\title{
The Role of luxS in the Fire Blight Pathogen Erwinia amylovora Is Limited to Metabolism and Does Not Involve Quorum Sensing
}

\author{
Fabio Rezzonico, ${ }^{1,2}$ and Brion Duffy ${ }^{2}$ \\ ${ }^{1}$ SafeCrop Centre, Istituto Agrario di S. Michele all'Adige, 38010 S. Michele all'Adige, Italy; ${ }^{2}$ Agroscope Changins-Wädenswil \\ ACW, 8820 Wädenswil, Switzerland
}

Submitted 15 February 2007. Accepted 2 June 2007.

Erwinia amylovora is a gram-negative phytopathogen that causes fire blight of pome fruit and related members of the family Rosaceae. We sequenced the putative autoinducer-2 (AI-2) synthase gene luxS from $E$. amylovora. Diversity analysis indicated that this gene is extremely conserved among $E$. amylovora strains. Quorum sensing mediated by LuxS has been implicated in coordinated gene expression, growth, and virulence in other enterobacteria; however, our evidence suggests this is not the function in $E$. amylovora. Mutational analysis pointed to a role in colonization of apple blossoms, the primary infection court for fire blight, although little if any role in virulence on apple shoots and pear fruit was observed. Expression of key virulence genes $h r p L$ and $d s p A / E$ was reduced in mutants of two $E$. amylovora strains. Stronger effects on gene expression were observed for metabolic genes involved in the activated methyl cycle with mutants having greater levels of expression. No quorum-sensing effect was observed in coculture experiments with wild-type and mutant strains either in vitro or in apple blossoms. Known receptors essential for AI-2 quorum sensing, the LuxPQ sensor kinase or the Lsr ABC-transporter, are absent in E. amylovora, further suggesting a primarily metabolic role for luxS in this bacterium.

Additional keywords: sulfur metabolism.

Fire blight, caused by the enterobacterium Erwinia amylovora, is one of the most devastating diseases of pome fruit and other rosaceous plants worldwide (Gordon Bonn and van der Zwet 2000). The most economically important phase of this disease is blossom blight originating from flower infections. The pathogen is spread during the flowering period from overwintering cankers or distant inoculum sources via pollinating insects (Thomson 2000) and, to a lesser extent, by physical dispersal. Under favorable environmental conditions (Thomson 2000) and in the presence of flower nectar, the pathogen population rapidly grows and enters the host via natural openings, nectarthodes. Once inside the host, the pathogen moves through the vascular system causing rapid death of shoots and, left unchecked, advances into the woody tissues, resulting in death of limbs and entire trees. Fire blight can spread rapidly, destroying entire orchards within a single season; however, even in infested areas, disease is unpredictable, with severe

Corresponding author: Fabio Rezzonico; Telephone: + 41447836331 , Fax: + 4144 7836305, E-mail: fabio.rezzonico@acw.admin.ch epidemics often followed by several years of low or absent severity. Although weather conditions play a major role in this phenomenon, many fundamentals of pathogen ecology (e.g., significance of survival on nonhost species) and interactions with host physiology (e.g., role of sorbitol flux in the host during vegetative growth) (Blachinsky et al. 2006) are still little understood.

Although E. amylovora was the first phytopathogenic bacterium described, the major virulence factors have begun to be elucidated only relatively recently. A number of genes have been identified that contribute to virulence, particularly those involved in production of the extracellular polysaccharide amylovoran and the functionality of a type-III secretion system (T3SS) (Oh and Beer 2005). The T3SS is controlled by the alternative $\sigma$-factor HrpL and leads ultimately to the secretion of the effector DspA/E, which is believed to disrupt host cell function and may be part of a gene-for-gene interaction (Bogdanove et al. 1998). Current control measures beyond prevention and eradication are limited, with the most effective approaches, antibiotic applications during flowering and biological control, relying primarily on direct inhibition of pathogen growth or via substrate competition (Elgoorani and Hassanein 1991; Johnson and Stockwell 1998; McManus et al. 2002; Stockwell et al. 2002). Understanding virulence mechanisms can lead to novel control options, as demonstrated by the development of chemical inducers of plant defense responses (Messenger) based on E. amylovora harpin proteins secreted by the T3SS (Wei et al. 1992). Novel biocontrol strategies have been developed against related bacteria, based on the suppression of multiple virulence factors through quenching of quorum-sensing-mediated global regulatory systems. Thus far, this approach has been effective for pathogens such as Pectobacterium carotovorum (ex. E. carotovora) that rely on an $N$-homoserine lactone autoinducer-1 signal (AI-1) (Lee et al. 2002; Molina et al. 2003). AI-1 has been described recently in E. amylovora (Molina et al. 2005; Venturi et al. 2004); however, a global regulatory function has not been confirmed with mutational analysis, and chemical or biological approaches targeting autoinduction repression remain to be explored in this pathogen.

A second quorum-sensing system (QS-2) reliant on LuxS as the enzyme responsible for signal (AI-2) production is well described in diverse animal-associated bacteria (Vendeville et al. 2005). AI-2 has been implicated in virulence of several bacteria, such as Vibrio cholerae (Miller et al 2002), Escherichia coli, and Salmonella typhimurium (Surette and Bassler 1999), and it has been postulated to facilitate the transition to pathogenic existence inside the host (Surette and Bassler 1998, 1999). Recently, the presence of $\operatorname{luxS}$ was described in the pectolytic 
enterobacterial phytopathogen $P$. carotovorum (Coulthurst et al. 2006; Laasik et al. 2006); however, the potential importance of AI-2 in plant-pathogen associations is still largely unknown. In members of Vibrionaceae (Bassler et al. 1994), the direct AI-2 precursor is (S)-4,5-dihydroxy-2,3-pentanedione (DPD), which is spontaneously transformed in the presence of borate (Winzer et al. 2002) into the actual AI-2 extracellular signal (furanosyl borate diester). This is the signal that then is detected by the two-component sensor kinase LuxPQ, and transduced inside the cell via the central signal relay protein LuxU and the terminal response regulator LuxO, which, together with $\sigma^{54}$, controls gene expression (Mok et al. 2003; Neiditch et al. 2005; Reading and Sperandio 2006). Enterobacteriaceae such as E. coli (Xavier and Bassler 2005) or Salmonella spp. (Surette and Bassler 1999) produce a different AI-2 signal that does not contain boron (i.e., [2R,4S]-2-methyl2,3,3,4-tetrahydroxytetrahydrofuran [R-THMF]) (Miller at al. 2004), which is imported by the luxS-regulated (Lsr) ATP binding cassette (ABC)-transporter (Taga et al. 2003; Xavier and Bassler 2005). In the cell, LsrK phosporylates the AI-2 molecule, which then functions as an autoinducer by derepressing the Lsr operon (Wang et al. 2005). However, how the AI-2 signal is transduced to control pathogenicity-related genes remains unclear. A novel quorum-sensing regulator, MqsR, was detected in E. coli $\mathrm{K} 12$, where it stimulates biofilm formation by stimulating flagellar motion and motility (González Barrios et al. 2006) via the response regulator QseB and sensor kinase QseC (Sperandio et al. 2002). Another protein, TqsA, was shown to control the export of AI-2 in the same strain (Herzberg et al. 2006). In Actinobacillus actinomycetemcomitans, the ArcB sensor kinase is thought to contribute to the signal transduction cascade that directs the LuxS-dependent expression of iron acquisition genes under iron limitation (Fong et al. 2003). Thus, multiple components in addition to luxS are essential in a functioning QS-2 system.

Further complicating an assessment of the role of $\operatorname{luxS}$ is the fact that its function may not be limited to AI- 2 synthesis. It is increasingly apparent that, in many bacteria, LuxS has a primary, or sole, role as a metabolic enzyme ( $S$-ribosylhomocysteinase) in the activated methyl cycle (AMC) (Winzer et al. 2003). The AMC is responsible for the generation of the major methyl donor $S$-adenosylmethionine (SAM) and the recycling of methionine by detoxification of $S$-adenosyl-L-homocysteine (SAH). LuxS takes part in this cycle by salvaging the homocysteine moiety from the cycle intermediate $S$-ribosyl homocysteine (SRH). As a by-product of this reaction, DPD, the direct AI-2 precursor, is formed. Bacteria lacking an intact AMC lose the ability to recycle methionine and, thus, are dependent on its uptake or synthesis from environmental sulfur sources. In complex media, this amino acid, along with inorganic anionic sulfur species, is plentifully available and this handicap poses little or no problem to the mutant; however, when sulfur becomes a limiting resource, the metabolic charge required for de novo synthesis of methionine will negatively influence its growth (Doherty et al. 2006).

Despite the dual role of this gene, many recent reports have simply drawn a direct correlation between the mere occurrence of luxS and the presence and functionality of QS-2, sometimes supporting this observation with mutant analysis and additional phenotypic tests, such as the use of AI-2 reporter strain $V$. harveyi BB170 (Surette and Bassler 1999). However, relatively little effort typically is placed on identification of critical AI-2 receptor candidates. Moreover, the true functionality of QS-2 rarely is assessed by performing a chemical complementation of luxSmutants using the pure AI-2 signal or supernatants of AI- 2 producers; instead, assumptions are made based on the usual in trans genetic complementation, which also would restore the activity of the AMC (Vendeville et al. 2005). The aims of this study were, first, to characterize luxS in Erwinia amylovora and, then, use mutational analysis to investigate its role or roles in metabolism, quorum sensing, ecology, and virulence.

\section{RESULTS}

Sequence analysis of the luxS gene in E. amylovora.

Amplification of the luxS gene, using primers based on the complete genome sequence (Sanger Institute website), was obtained for all 21 E. amylovora strains analyzed. Representative examples of the complete sequence have been deposited in the National Center for Biotechnology Information (NCBI) database (accession numbers DQ457094 and DQ457095). Sequence information also was obtained for epiphytic $E$. billingiae LMG2613 (accession number DQ977724). Sequence analysis indicates that the 516 nucleotides of the $\operatorname{luxS}$ gene were identical in all but one E. amylovora strain analyzed (DQ457094, represented by E. amylovora CFBP1430), despite the fact that these were derived from genotypically diverse strains of worldwide origin which were isolated from different host plants. The only exception was E. amylovora FAW611 (DQ457095), which displayed two base-pair substitutions at positions 109 and 112 that resulted in a single substitution of aspartic acid with cognate acidic amino acid glutamic acid. Phylogenetic analysis indicates that the deduced amino acid sequence of LuxS of E. amylovora is most related to that of E. tasmaniensis (identity $98.2 \%$ ) and E. billingiae (identity $90.1 \%$ ), with sequences from other members of Enterobacteriaceae, such as $P$. carotovorum, S. marcescens, or Yersinia spp. (identity $>85.4 \%$ ), showing a more pronounced differentiation (Fig. 1).

\section{Absence of known AI-2 receptor genes in E. amylovora.}

In silico analysis was performed with E. amylovora in order to find other AI-2 quorum-sensing-related genes. No homologues of the $\operatorname{lux} P Q$ genes coding for two-component AI-2 receptor of $V$. harveyi or the luxOU genes encoding the associated transduction pathway were found in the completed genome of E. amylovora Ea273 produced by the Erwinia amylovora Sequencing Group at the Sanger Institute in Cambridge, U.K. Although it is true that different proteins showed a moderate homology $(\leq 51.3 \%)$ with the C-terminal domain (from position 1,225 to the end of the open reading frame) of $V$. harveyi LuxQ sensor kinase/phosphatase (accession number P54302), it must be noted that this region corresponds to the histidine kinase A, the histidine kinase-like ATPase, and the signal receiver domains of the LuxQ protein. In fact, these hits correspond merely to the cytoplasmic signal-transduction domain of other E. amylovora sensor kinases. Along the same line, no homologue of the Lsr operon, responsible for the transport and processing of AI-2 in S. typhimurium and other members of Enterobacteriaceae, or of the Escherichia coli quorumsensing regulators MqsR, QseBC, and exporter TqsA, could be found in Erwinia amylovora Ea273. Finally, the A. actinomycetemcomitans $\mathrm{ArcB}$ sensor kinase did not yield any match in the E. amylovora genome and a search limited to Erwinia spp. of all NCBI databases with relevant functional terms associated with the second quorum-sensing system (e.g., AI-2, LuxS, LuxP, LuxQ, lsr operon, AI-2 receptor, and so on) yielded positive matches only for autoinducer-production protein LuxS, but not for any of the known receptors or AI-2-associated signal transduction proteins.

\section{Construction and verification} of luxS mutants and complementation of defective strains.

E. amylovora luxS mutants were constructed in two strains using polymerase chain reaction (PCR) to obtain a $2.1-\mathrm{kb}$ 
BamHI assembly of the flanking regions of a luxS from strain CFBP1430. This was interrupted with an $\Omega$ cassette carrying a kanamycin resistance gene and cloned into the suicide vector pCAM-MCS (Burse et al. 2004). The resulting plasmid, named pCAM-A $\Omega B$, was mobilized into rifampicin-resistant strains CFBP1430 and FAW610 by biparental mating with Escherichia coli S17-1 $\lambda$-pir. Double homologue recombination in Erwinia amylovora was sought by overnight incubation at $28^{\circ} \mathrm{C}$ and isolation of the resulting colonies based on kanamycin and rifampicin resistance and tetracycline sensitivity on Chromocult coliform agar. Correct integration of the $\Omega$ cassette was verified in parallel PCRs using primers corBext1/ agemO and gshAext/Omega, respectively (data not shown).

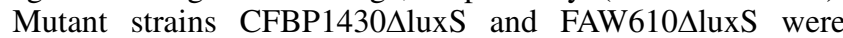
complemented in trans by electroporation with the plasmid pMF8805 carrying the intact luxS gene of strain CFBP1430 controlled by its own promoter, yielding strains CFBP1430 $\Delta+$ and FAW610 $\Delta+$, respectively.

Complete knock-out of the synthesis of $\operatorname{luxS} \mathrm{mRNA}$ in the two mutants and its restoration in the complemented strains was confirmed using reverse-transcription (RT)-PCR (Fig. 2). Similarly, a modest activation of the biosensor strain $V$. harveyi BB170 was confirmed by means of cross-feeding assays in wild-type and complemented strains, but not in the mutant (Table 1). However, this value, on average, was never higher than the value (i.e., $10 \%$ of the stimulation by $V$. harveyi BB120) which commonly is considered to be the threshold for a positive evaluation of the assay (Bassler et al. 1997).

\section{Bacterial growth under sulfur-limiting conditions.}

A straight approach to understand whether the luxS-deficient phenotype is to be ascribed to defective quorum sensing or is

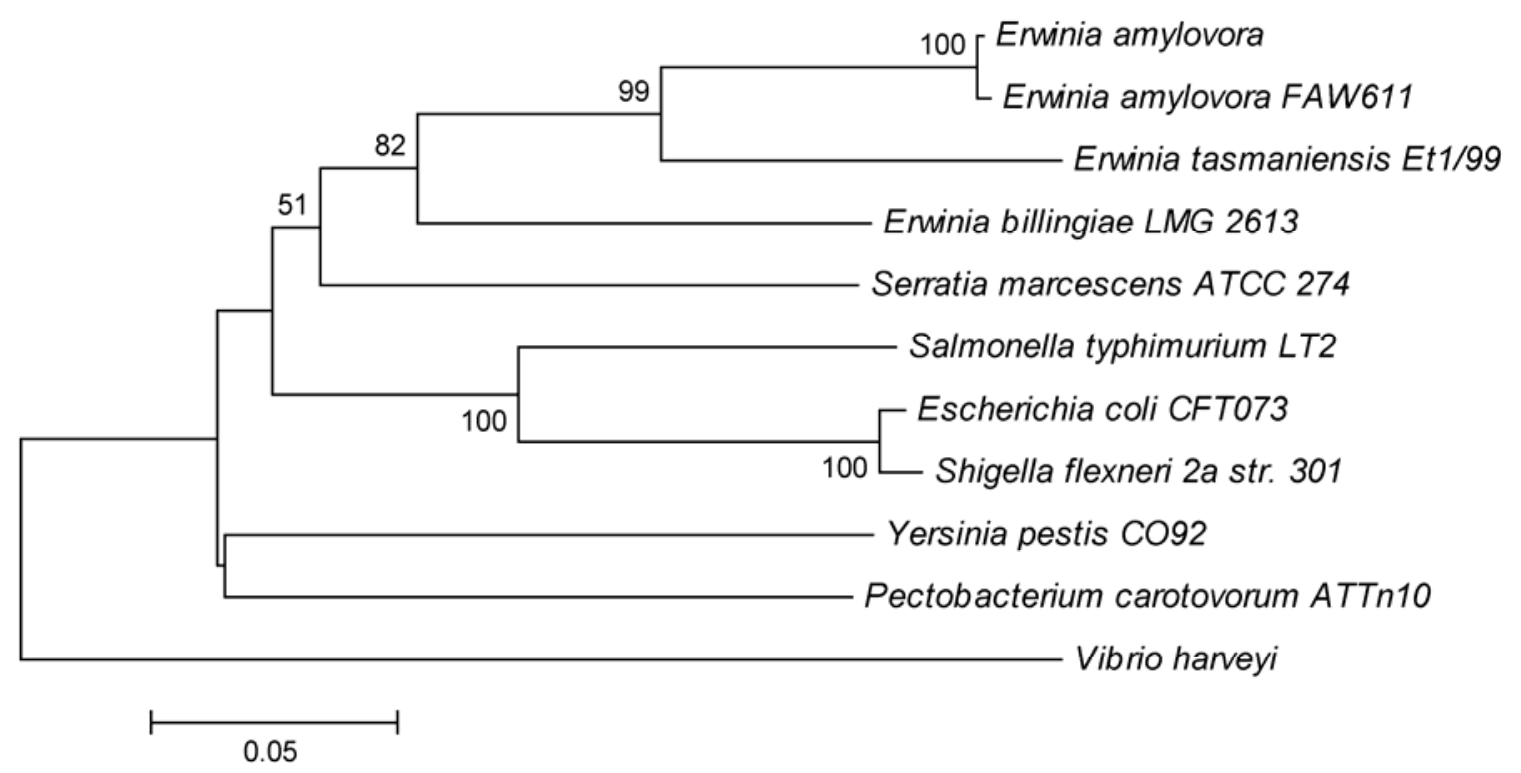

Fig. 1. Phylogenetic relationships on the basis of complete luxS sequences between different bacteria belonging to the family of Enterobacteriaceae. The distance tree was generated by the neighbor-joining method with the Jukes-Cantor formula, using Vibrio harveyi as outgroup. Nodal supports were assessed by 1,000 bootstrap replicates. Only bootstrap values greater than $50 \%$ are shown. The scale bar represents the number of substitutions per site. With the exception of Erwinia amylovora and E. billingiae LMG 2613 sequences, which were produced in this work, all luxS sequences were retrieved at the National Center for Biotechnology Information database or in published genomes projects: E. tasmaniensis Et1/99 (AM117930), Serratia marcescens ATCC 274 (AJ628150), Salmonella typhimurium LT2 (NC_003197), Escherichia coli CFT073 (AE014075), Shigella flexneri 2a str. 301 (NC_004337), Yersinia pestis CO92 (AL590842), Pectobacterium carotovorum ATTn10 (AJ628151), and V. harveyi (AF120098). Erwinia amylovora represents the ensemble of all E. amylovora strains examined in this work, which shared $100 \%$ consensus, with the exception of strain FAW611.
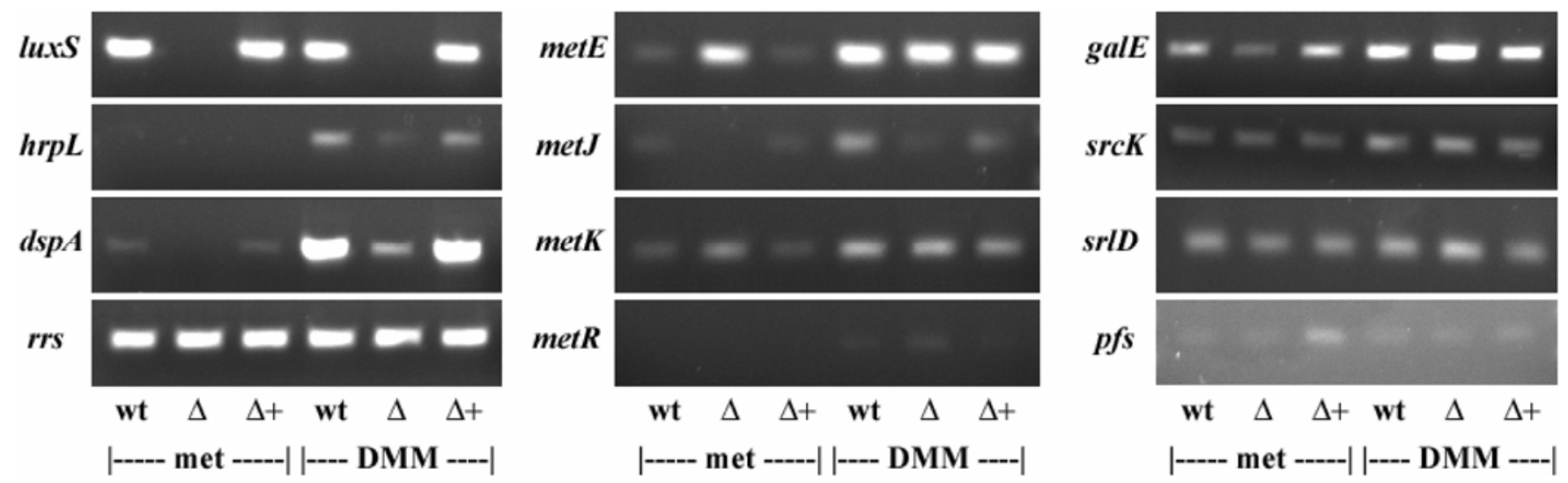

Fig. 2. Effect of the luxS mutation on the expression of several pathogenicity-related and metabolic genes of Erwinia amylovora FAW610. Genetic expression was assessed by semiquantitative reverse-transcription polymerase chain reaction in wild-type (wt), luxS mutant ( $\Delta$ ), and complemented strain $(\Delta+)$ in both Davis minimal medium (DMM) and modified DMM with $100 \mu \mathrm{M}$ methionine as sole sulfur source (met). The picture shows the expression of all genes after $16 \mathrm{~h}$ of cultivation (middle of the exponential growth phase) except for metJ, metR, and $p f s$, which were below detection at that time and are shown after $26 \mathrm{~h}$ (end of the exponential growth phase). Expression of $r r s$ (encoding 16S-rRNA) was confirmed to be constitutive throughout all growth phases and was validated as a control for sample normalization. 
due merely to an interrupted metabolic process is to test the growth of the mutant with methionine (which is part of the AMC) or the other sulfur-containing amino acid (cysteine) as sole sulfur source, and to compare the result with bacteria grown in media where this chemical element is not a limiting factor. Cultivation experiments showed that the growth of E. amylovora FAW610 luxS mutant strains generally was unaffected compared with the corresponding wild-type or complemented strains in rich media such as Luria-Bertani (LB) (Fig. 3A) or in normal Davis minimal medium (DMM) (Fig. 3D), where the total $\mathrm{SO}_{4}^{-}$concentration is as high as $8.4 \mathrm{mM}$. All strain derivatives reached absorbance values of up to 0.870 and 0.710 ,

Table 1. Luminescence induction of the AI-2 biosensor Vibrio harveyi BB170 by cell-free supernatants of Erwinia amylovora CFBP1430 and FAW610 strain derivatives ${ }^{\mathrm{a}}$

\begin{tabular}{lcccc}
\hline Strain $^{\text {b }}$ & AB & LB & Davis & hrp \\
\hline V. harveyi BB120 & 100 & nd & nd & nd \\
CFBP1430 & $6.5( \pm 1.0)$ & $7.5( \pm 3.4)$ & $8.5( \pm 2.7)$ & $9.5( \pm 1.0)$ \\
CFBP1430 1 luxS & bd & $0.3( \pm 0.3)$ & bd & $0.7( \pm 0.6)$ \\
CFBP1430 + & $7.0( \pm 2.7)$ & $6.5( \pm 0.9)$ & $8.0( \pm 2.0)$ & $10( \pm 2.7)$ \\
FAW610 & $4.0( \pm 1.5)$ & $6.5( \pm 1.7)$ & $6.5( \pm 1.7)$ & $9.0( \pm 1.8)$ \\
FAW610 1 luxS & bd & $0.3( \pm 0.3)$ & bd & $0.7( \pm 0.6)$ \\
FAW610 $\Delta+$ & $5.0( \pm 2.7)$ & $7.5( \pm 1.0)$ & $6.5( \pm 0.0)$ & $9.5( \pm 3.1)$ \\
\hline
\end{tabular}

${ }^{\text {a }}$ E. amylovora was grown for $14 \mathrm{~h}$ at $28^{\circ} \mathrm{C}$ in four different culture media and spent supernatants were added $(1: 10 \mathrm{vol} / \mathrm{vol})$ to newly inoculated cultures of Vibrio harveyi BB170 Luminescence was measured after $4 \mathrm{~h}$ of incubation at $30^{\circ} \mathrm{C}$.

${ }^{a}$ Values represent percent induction with respect to the response of the biosensor when grown in autoinducer assay broth $(\mathrm{AB})$ medium (1:10 $\mathrm{vol} / \mathrm{vol})$ supplemented with spent $V$. harveyi BB120 supernatant ( \pm standard deviation). $\mathrm{LB}=$ Luria-Bertani medium, $\mathrm{nd}=$ not determined, and $\mathrm{bd}=$ below detection. respectively, at the end of the exponential growth phase. Nevertheless, in DMM, unlike the wild-type or complemented strain, the luxS mutant showed a loss in turbidity (i.e., decrease in absorbance) after reaching the stationary phase at $40 \mathrm{~h}$ (Fig. 3D). In the modified sulfate-free DMM where methionine (met) was present at $100 \mu \mathrm{M}$-concentration as the sole sulfur source, the growth of the luxS mutant was considerably impaired, attaining an absorbance that was lower $(0.235)$ than that attained by the wild-type (0.428) or the complemented strain (0.435) (Fig. 3B). Similar results were obtained at $50 \mu \mathrm{M}$ (data not shown), whereas this gap was noticeably narrower when the concentration of methionine in the medium was only $10 \mu \mathrm{M}$ (Fig. 3C). Conversely, if just cysteine (cys) was present as a sole sulfur source in the medium, no differences in bacterial growth could be observed at $100 \mu \mathrm{M}$ (Fig. 3E) or $50 \mu \mathrm{M}$ (data not shown), with the concentration of all three derivatives reaching absorbance values of up to 0.890 and 0.750 , respectively. At $50 \mu \mathrm{M}$, however, the density of the mutant strain in stationary phase dropped slightly to an absorbance value of 0.621 after $72 \mathrm{~h}$. Unlike results in media with $100 \mu \mathrm{M}$ with methionine, impairment of mutant growth relative to the wild-type or complemented strain was observed only at low $(10 \mu \mathrm{M})$ cysteine concentration (Fig. 3F).

\section{Bacterial growth in coinoculated cultures.}

In order to understand whether the $\operatorname{luxS}$-deficient phenotype really involves quorum sensing, we tested whether the wildtype or the complemented strain were able to relieve the growth deficit of the luxS mutant by the means of extracellular factors in cocultivation experiments under sulfur-limiting conditions. In DMM, all strain derivatives reached concentrations of up to $3 \times 10^{9} \mathrm{CFU} \mathrm{ml} \mathrm{m}^{-1}$ at the end of the exponential growth
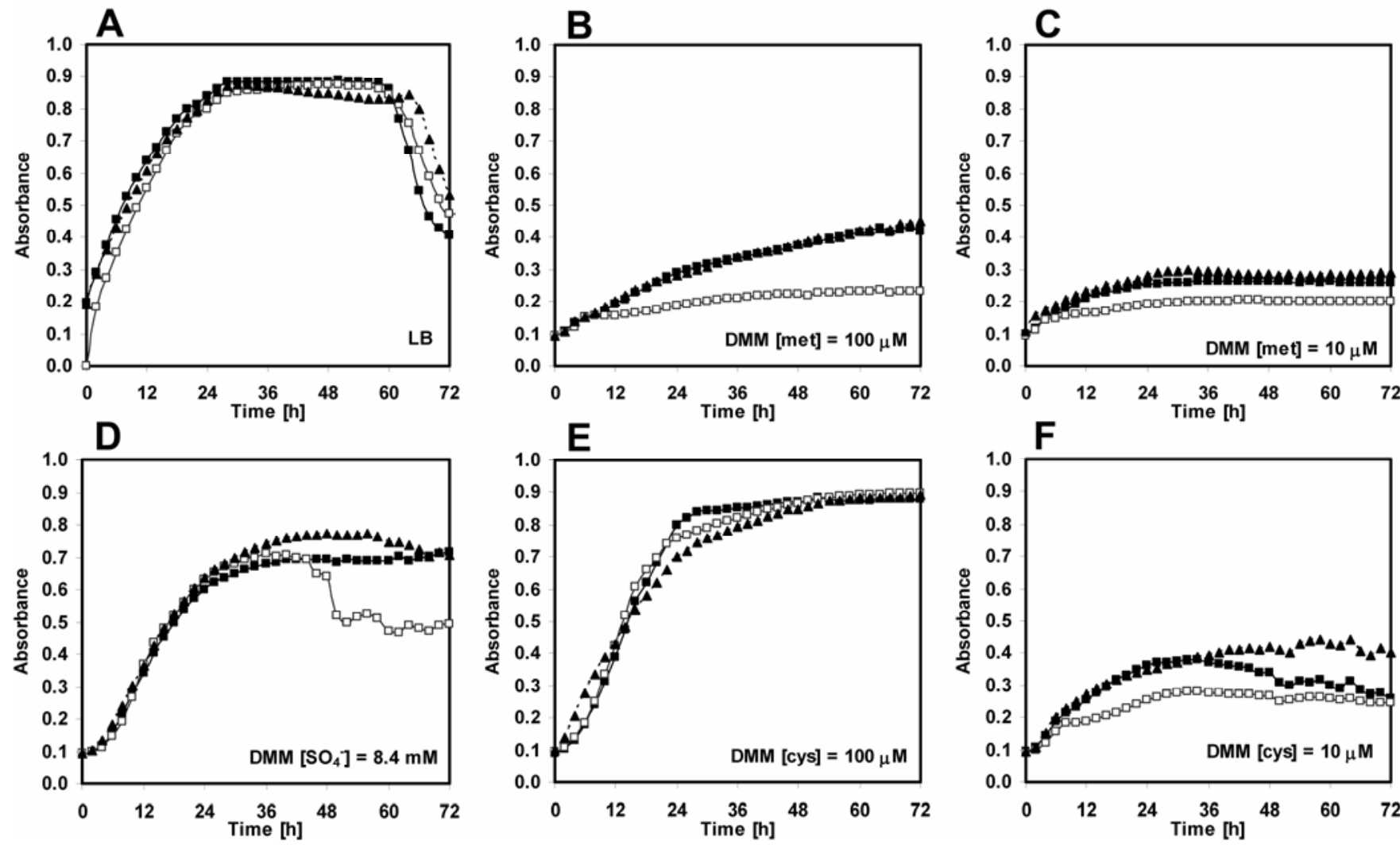

Fig. 3. Effect of sulfur limitation on the growth of Erwinia amylovora FAW610 derivatives. The bacteria were cultivated in $200-\mu 1$ microcultures at $28^{\circ} \mathrm{C}$ in sulfur-rich media using $\mathbf{A}$, Luria-Bertani medium or $\mathbf{D}$, Davis minimal medium (DMM $\left[\mathrm{SO}_{4}^{-}\right]=8.4 \mathrm{mM}$ ) or under sulfur limitation in modified DMM with B, $100 \mu \mathrm{M}$ or $\mathbf{C}, 10 \mu \mathrm{M}$ methionine (DMM [met] and $\mathbf{E}, 100 \mu \mathrm{M}$ or $\mathbf{F}, 10 \mu \mathrm{M}$ cysteine (DMM [cys] as sole sulfur sources. The wild type is represented by black squares ( $\square)$, the luxS mutant by empty squares $(\square)$, and the complemented strain by black triangles $(\mathbf{\Lambda})$. 
phase whereas, in the modified sulfate-free DMM where methionine (met) was present at a concentration of $100 \mu \mathrm{M}$ as the sole sulfur source, the growth of the $\operatorname{luxS}$ mutant was considerably impaired, attaining a cell number that was lower $(3.4 \times$ $\left.10^{8} \mathrm{CFU} \mathrm{m}^{-1}\right)$ than that of the wild-type $\left(9.4 \times 10^{8} \mathrm{CFU} \mathrm{ml}^{-1}\right)$ or the complemented strain $\left(8.7 \times 10^{8} \mathrm{CFU} \mathrm{ml}^{-1}\right)$ (Fig. 4A). This phenotype was not relieved under coculture conditions, when wild-type and isogenic mutant strains (Fig. 4B) where coinoculated at the same concentration in one flask. The growth of the coinoculated strains was again comparable in normal DMM, reaching cell densities of $1.7 \times 10^{9} \mathrm{CFU} \mathrm{ml} l^{-1}$, but not in the modified sulfate-free DMM, where the mutant growth was only approximately one-fifth $\left(1.7 \times 10^{8} \mathrm{CFU} \mathrm{ml} \mathrm{m}^{-1}\right)$

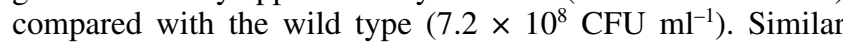
results where obtained when the coinoculation experiment was performed using the mutant and complemented strain (Fig. 4C). In normal DMM, both strains reached comparable cell densities $\left(1.8 \times 10^{9}\right.$ and $1.9 \times 10^{9} \mathrm{CFU} \mathrm{ml}^{-1}$, respectively); however, under sulfur-limiting conditions, the complemented strain $\left(6.7 \times 10^{8} \mathrm{CFU} \mathrm{ml^{-1 }}\right)$ was more competitive than the luxS mutant $\left(2.4 \times 10^{8} \mathrm{CFU} \mathrm{ml}^{-1}\right)$.

\section{Genetic expression in luxS mutants.}

Semiquantitative RT-PCR confirmed the complete knockout of the $\operatorname{luxS}$ gene in the corresponding mutant in all strain derivatives and throughout all growth phases, and the constitutive expression of the $r r s$ gene which, therefore, was validated as internal control for sample normalization (Fig. 2). The expression of carbon metabolism genes generally was not affected appreciably in the $\operatorname{luxS}$ mutant, and was modulated only by the growth phase of the bacterial culture or the growth medium used. For galE, this stands in contrast with a previous report that suggested that this gene (coding for UDP-galactose 4epimerase) is expressed constitutively by E. amylovora (Metzger et al. 1994). In fact, of all carbon metabolism genes analyzed, only the transcription of galE showed a general decline in the luxS mutant, especially after reaching the end of the exponential growth phase (Table 2).

Conversely, the luxS mutation had an unequivocal impact on the expression of genes that are related to the AMC. Expression of metE, metK, and $m e t R$ (activator) was upregulated, whereas $p f s$ and especially metJ (repressor) were downregu- lated in the $\operatorname{luxS}$ mutants, particularly when bacteria where cultured in modified DMM with methionine as sole sulfur source (Fig. 2). The expression of the regulatory gene hrpL, encoding the T3SS-specific $\sigma$ factor, which was evident only in DMM, was downregulated in the $\operatorname{luxS}$ mutant throughout the entire exponential growth phase. The expression of the pathogenicity-related gene $d s p A$, encoding for a T3SS-secreted

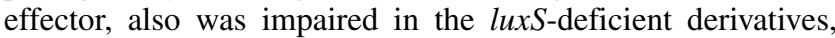
possibly due to the reduced transcription of the positive regulatory gene. Again, this effect on $d s p A$ was more evident under sulfur limitation in modified DMM (Fig. 2).

\section{Motility and biofilm assays.}

Swimming and swarming were assessed by measuring the distance covered by the bacteria from the original spotting point after $48 \mathrm{~h}$ of growth at $23^{\circ} \mathrm{C}$ on semiliquid agar. The spreading pattern of the colony was similar for both strains and in all agar concentration tested $(0.3,0.5$, and $0.8 \%)$, with the development of three circular concentric zones (chemotactic rings) of apparently different cell densities. The diameter of each zone was measured, but no significant difference in swimming or swarming was detected between the wild-type strains and their derivatives in media with a range of 0.3 to $0.8 \%$ agarose. Illustrative results for the $0.3 \%$ agar concentration (swimming) are displayed in Table 3. Strains FAW610 and CFBP1430 were equally able to form a biofilm in rich medium (LB, SOBG [20 g of tryptone, $5 \mathrm{~g}$ of yeast extract, $0.5 \mathrm{~g}$ of $\mathrm{NaCl}, 2.4 \mathrm{~g}$ of $\mathrm{MgSO}_{4}, 0.186 \mathrm{~g}$ of $\mathrm{KCl}$, and $2 \%$ glycerol per liter], or SOCG [SOBG supplemented with $20 \mathrm{mM}$ glucose]) at both temperatures tested $\left(24\right.$ or $\left.30^{\circ} \mathrm{C}\right)$. No difference between wild-type, mutant, and complemented strains was observed in biofilm development in stationary cultures of E. amylovora grown for 2 weeks in the above media.

\section{Colonization of detached apple blossoms.}

Population sizes of E. amylovora FAW610 strain derivatives were assessed after artificial inoculation in the hypanthium of detached apple blossoms in order to determine the role of luxS in bacterial colonization ability. Each flower originally was inoculated with a population of $\approx 10^{2} \mathrm{CFU} /$ flower of the respective strain derivative, which increased after 2 days of incubation to $5.3 \times 10^{8}$ and $6.3 \times 10^{8} \mathrm{CFU} /$ flower in the wild-type and the

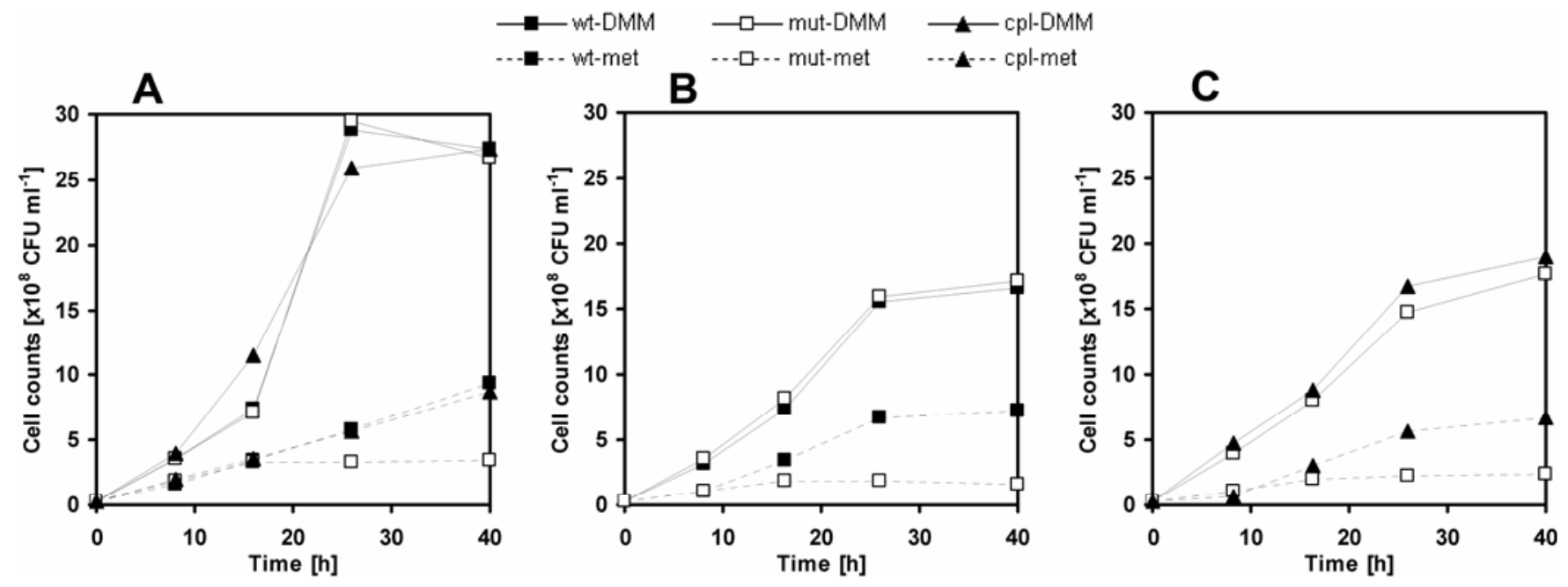

Fig. 4. Competition experiments between $\operatorname{luxS}$-positive and $\operatorname{luxS}$-negative Erwinia amylovora FAW610 derivatives. The failure of luxS-positive strains to complement E. amylovora FAW610 $\operatorname{luxS}$ in co-cultivation assay is indicative of the absence of an extracellular signal. The bacteria were cultivated at $28^{\circ} \mathrm{C}$ in Davis minimal medium (DMM $\left[\mathrm{SO}_{4}^{-}\right]=8.4 \mathrm{mM}$ ) (solid line) or under sulfur-limiting conditions in modified DMM with methionine $[$ met] $=100 \mu \mathrm{M}$ as sole sulfur source (dotted line) in either $\mathbf{A}$, separate cultures or $\mathbf{B}$, a 1:1 ratio of wild-type/mutant and $\mathbf{C}$, mutant/complemented strain at a starting optical density at $600 \mathrm{~nm}=0.018$. Bacteria were enumerated by colony counts on Luria-Bertani supplemented with the appropriate antibiotics. The wild type is represented by black squares ( $\mathbf{\square})$, the luxS mutant by empty squares ( $\square)$, and the complemented strain by black triangles ( $\mathbf{A})$. 
Table 2. Expression of metabolic and pathogenicity related genes in Erwinia amylovora FAW610 strain derivatives during growth in Davis minimal medium (DMM) or modified DMM with $100 \mu \mathrm{M}$ methionine (met) as sole sulfur source ${ }^{\mathrm{a}}$

\begin{tabular}{|c|c|c|c|c|c|c|}
\hline \multirow[b]{2}{*}{ Gene, $t$ (h) } & \multicolumn{3}{|c|}{ met } & \multicolumn{3}{|c|}{ DMM } \\
\hline & wt & $\Delta$ & $\Delta+$ & wt & $\Delta$ & $\Delta+$ \\
\hline \multicolumn{7}{|l|}{$\operatorname{lux} S$} \\
\hline 16 & 1.18 & bd & 1.15 & 1.09 & bd & 1.05 \\
\hline 26 & 1.2 & bd & 1.36 & 1.27 & bd & 1.08 \\
\hline 40 & 1.47 & bd & 1.44 & 1.25 & bd & 1.12 \\
\hline \multicolumn{7}{|l|}{$h r p L$} \\
\hline 16 & bd & bd & bd & 0.4 & 0.08 & 0.26 \\
\hline 26 & bd & bd & bd & 0.27 & 0.02 & 0.18 \\
\hline 40 & bd & bd & bd & bd & bd & bd \\
\hline \multicolumn{7}{|l|}{$d s p A$} \\
\hline 16 & 0.08 & bd & 0.08 & 1.18 & 0.44 & 1.2 \\
\hline 26 & 0.83 & bd & 0.82 & 1.26 & 1.05 & 1.13 \\
\hline 40 & 1.15 & bd & 1.08 & 1.43 & 1.33 & 1.31 \\
\hline \multicolumn{7}{|l|}{ metE } \\
\hline 16 & 0.12 & 0.95 & 0.07 & 1.12 & 1.16 & 1.01 \\
\hline 26 & 0.06 & 0.66 & bd & 1.1 & 1.24 & 0.98 \\
\hline 40 & bd & bd & bd & 0.95 & 1.33 & 0.89 \\
\hline \multicolumn{7}{|l|}{ metJ } \\
\hline 16 & 0.01 & 0.01 & 0.02 & 0.03 & 0.01 & 0.01 \\
\hline 26 & 0.11 & bd & 0.06 & 0.49 & 0.02 & 0.17 \\
\hline 40 & 0.15 & bd & 0.25 & 1.31 & 0.17 & 0.52 \\
\hline \multicolumn{7}{|l|}{$\operatorname{met} K$} \\
\hline 16 & 0.15 & 0.34 & 0.1 & 0.46 & 0.4 & 0.32 \\
\hline 26 & 0.05 & 0.49 & 0.12 & 0.53 & 0.63 & 0.7 \\
\hline 40 & 0.29 & 0.94 & 0.43 & 0.95 & 0.66 & 0.93 \\
\hline \multicolumn{7}{|l|}{ metR } \\
\hline 16 & bd & bd & bd & bd & bd & bd \\
\hline 26 & bd & bd & 0.01 & 0.04 & 0.06 & 0.01 \\
\hline 40 & 0.02 & 0.25 & 0.01 & 0.39 & 0.82 & 0.12 \\
\hline \multicolumn{7}{|l|}{ galE } \\
\hline 16 & 0.55 & 0.21 & 0.69 & 0.88 & 1.08 & 0.75 \\
\hline 26 & 0.45 & 0.05 & 0.56 & 0.79 & 0.07 & 0.46 \\
\hline 40 & 0.55 & 0.13 & 0.54 & 0.53 & 0.05 & 0.52 \\
\hline \multicolumn{7}{|l|}{$\operatorname{src} K$} \\
\hline 16 & 0.14 & 0.15 & 0.13 & 0.39 & 0.41 & 0.31 \\
\hline 26 & 0.32 & 0.53 & 0.66 & 0.8 & 0.39 & 0.55 \\
\hline 40 & 0.89 & 0.6 & 0.61 & 0.67 & 0.92 & 0.78 \\
\hline \multicolumn{7}{|l|}{$s r l D$} \\
\hline 16 & 0.44 & 0.3 & 0.36 & 0.41 & 0.49 & 0.3 \\
\hline 26 & 0.7 & 0.54 & 0.72 & 0.56 & 0.6 & 0.58 \\
\hline 40 & 0.64 & 0.58 & 1 & 1.65 & 1.08 & 1.01 \\
\hline \multicolumn{7}{|l|}{$p f s$} \\
\hline 16 & bd & bd & bd & bd & bd & bd \\
\hline 26 & 0.03 & 0.03 & 0.27 & 0.09 & 0.04 & 0.07 \\
\hline 40 & 0.04 & bd & 0.04 & 0.04 & 0.05 & 0.08 \\
\hline \multicolumn{7}{|l|}{$r r s^{\mathrm{b}}$} \\
\hline 16 & 1,823 & 1,986 & 1,879 & 2,027 & 1,856 & 2,103 \\
\hline 26 & 1,947 & 1,909 & 1,711 & 1,702 & 1,890 & 1,909 \\
\hline 40 & 1,703 & 1,791 & 1,651 & 1,439 & 1,705 & 1,677 \\
\hline
\end{tabular}

a The expression of different genes was measured as the intensity of densitometric signals obtained after semiquantitative reverse-transcription polymerase chain reaction (RT-PCR). All values were calculated relative to the absolute value (shown in italics) obtained for rrs (constitutively expressed control) and are comparable only within the same gene; bd = below detection, $t=$ time in hours, and wt $=$ wild type; $\Delta=$ mutant, $\Delta+=$ comple mented mutant.

b Absolute densitometric intensity obtained after 25 cycles of RT-PCR using rrs-primers (used for normalization). complemented strain, respectively. The colonization ability of the luxS mutant was noticeably impaired, being approximately a log-value lower $\left(6.1 \times 10^{7} \mathrm{CFU} /\right.$ flower) (Fig. 5).

In order to observe its competitiveness in apple blossoms and to evaluate whether its hypothetical loss of AI-2 production could be complemented by the same compound produced by the intact gene product, the luxS mutant also was coinoculated on the flowers in a 1:1 mix with either the wild-type or the complemented strain derivative. The results obtained were comparable with those achieved when the bacteria were inoculated individually. In both cases, the population size of the luxS mutant was approximately an order of magnitude lower $(3.3 \times$ $10^{7}$ respectively $2.1 \times 10^{7} \mathrm{CFU} /$ flower) relative to those obtained for the wild-type $\left(5.4 \times 10^{8} \mathrm{CFU} /\right.$ flower $)$ and the complemented $\left(5.2 \times 10^{8} \mathrm{CFU} /\right.$ flower $)$ strain.

\section{Virulence assay on young apple shoots.}

The role of luxS in virulence was assessed on 1-year-old 'Golden Delicious' grafted plants inoculated with a range of bacterial concentrations $\left(10^{3}\right.$ to $\left.10^{9} \mathrm{CFU} \mathrm{ml}^{-1}\right)$. The level of disease measured as percent lesion length increased with higher inoculum concentrations (Fig. 6). However, no differences in virulence were observed when the mutant, complemented mutant, and wild-type strain were compared at any inoculum concentration (Fig. 6). No infection was evident with any of the three strains at the lowest inoculum concentration $\left(10^{3} \mathrm{CFU} \mathrm{ml} \mathrm{m}^{-1}\right)$. The formation of characteristic bacterial ooze was observed in most plants inoculated with $10^{5} \mathrm{CFU} \mathrm{ml}^{-1}$ or higher, regardless of the presence of a functioning luxS. Similar results showing a lack of difference in strains at any inoculum concentration were obtained in a second trial; however, the overall level of disease was lower, preventing pooling of the data. Similarly, no difference in disease severity was obtained in a preliminary trial performed using $10^{9} \mathrm{CFU} \mathrm{ml} \mathrm{m}^{-1}$ suspensions of individual strain derivatives from $E$. amylovora FAW610 and CFBP1430 on 6-week-old apple seedlings grown from Golden Delicious fruit (data not shown).

\section{Virulence assay on immature pear.}

Regardless of the starting concentration of the inoculum, no significant difference was observed in the diameter of the lesion formed on the surface of immature pear fruit inoculated with the luxS mutants of FAW610 compared with the wild-type or complemented strains. The wild-type and complemented strains also were not more efficient in colonizing the fruit tissue than the corresponding mutant strain at any inoculum concentration (Fig. 7). The final concentration of bacteria in the pear tissues was similar in all cases, even if the inoculum concentration varied by four orders of magnitude. A comparison between the virulence and colonization of $l u x S$ derivatives was performed with similar results also for strain CFBP1430 using an inoculum containing $10^{7} \mathrm{CFU} \mathrm{ml}^{-1}$ (data not shown).

\section{DISCUSSION}

The luxS gene product first was described as the enzyme responsible the production of AI-2, the extracellular signal molecule regulating the expression of luminescence by the means

Table 3. Effect of luxS mutation on motility of Erwinia amylovora CFBP1430 and FAW610 strain derivatives

\begin{tabular}{|c|c|c|c|c|c|c|}
\hline Strain $^{a}$ & CFBP & CFBPAluxS & CFBP $\Delta+$ & FAW610 & FAW610 $\Delta$ lux $S$ & FAW610 $\Delta+$ \\
\hline Zone 1 & $0.30 \pm 0.06$ & $0.32 \pm 0.04$ & $0.27 \pm 0.05$ & $0.30 \pm 0.06$ & $0.33 \pm 0.05$ & $0.32 \pm 0.08$ \\
\hline Zone 2 & $1.65 \pm 0.05$ & $1.72 \pm 0.04$ & $1.58 \pm 0.12$ & $1.60 \pm 0.09$ & $1.80 \pm 0.13$ & $1.68 \pm 0.15$ \\
\hline Zone 3 & $3.28 \pm 0.25$ & $3.38 \pm 0.31$ & $3.52 \pm 0.16$ & $3.45 \pm 0.29$ & $3.35 \pm 0.41$ & $2.90 \pm 0.43$ \\
\hline
\end{tabular}

${ }^{\text {a }}$ Swimming behavior was assessed after $48 \mathrm{~h}$ of incubation at $24^{\circ} \mathrm{C}$ in $0.3 \%$ Luria-Bertani agar. Values represent the diameter of the different zones (chemotactic rings) expressed in centimeters ( \pm standard deviation). 
of the second quorum-sensing system in $V$. harveyi (Bassler et al. 1993). A crucial role of LuxS in the AMC and in sulfur metabolism subsequently has become evident in certain bacteria (Winzer et al. 2002). Many studies, focused on different bacterial strains, have assumed that the presence of a functional luxS gene was a sufficient condition for the existence of an AI2-based quorum-sensing system in the corresponding bacteria (Winzer et al. 2003).

E. amylovora strains were collected on three different continents and on different host plants and represent the wide genotypic diversity of this pathogen (Jock et al. 2002). Nevertheless, all E. amylovora strains had the luxS gene, with 20 of 21 having $100 \%$ homology, and one (FAW611) differing in just $2 \mathrm{bp}$, resulting in one substitution between two cognate acidic amino acids. This result strongly suggests that this gene is of great importance for the biology of the fire blight pathogen. However, the fact that no homologues of known AI-2 receptors, exporters, or QS-2 regulators could be identified, either in the finished genome assembly of the E. amylovora Ea273 or through BLAST searching of other published E. amylovora sequences, casts substantial doubts on the existence of an AI-2-based quorum-sensing system in the fire blight pathogen and on the possible role of $\operatorname{luxS}$ as a key enzyme for the production of an AI-2 signal in this pathogen. Although it was not unexpected that no significant homology could be found to the LuxPQ two-component sensor kinase (a receptor that, thus far, was found only in the Vibrionaceae family) or the MqsR quorum-sensing regulator (which has been reported in association with QS-2 exclusively in Escherichia coli), the absence from the Erwinia amylovora genome of an Lsr receptor-complex (similar to the one found in Escherichia coli, Salmonella typhimurium, and other members of Enterobacteriaceae) was more surprising. The same is true also for the TqsA exporter or the QseBC and ArcB sensor kinases, which are also widespread in the Enterobacteriaceae family, even in species that do not display the familiar Lsr receptor (unpublished data). The absence of QseC homologs suggests that Erwinia amylovora also does not possess the critical components of a third quorum-sensing system recently described in Escherichia coli $\mathrm{O} 157: \mathrm{H7}$. In this strain, LuxS is not directly involved in synthesis of a QS-3 signal molecule; however, luxS

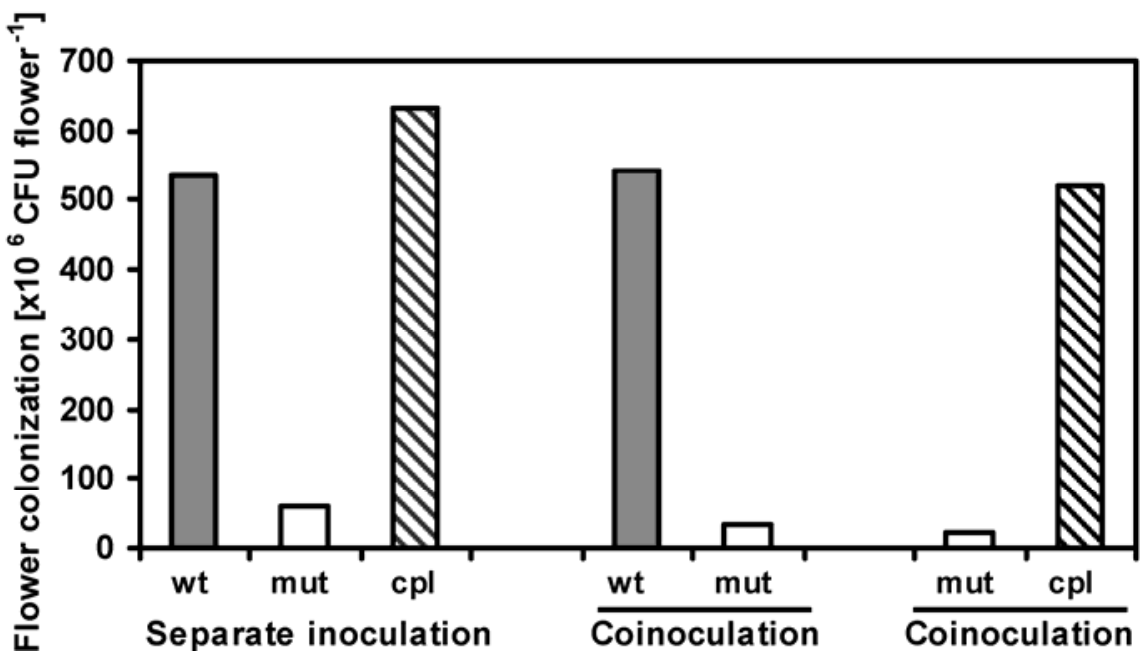

Fig. 5. Erwinia amylovora FAW610 colonization of detached 'Golden Delicious' apple flowers. Each flower was inoculated in the stigma or hypanthium with a suspension containing approximately $10^{2} \mathrm{CFU}$ of a single strain derivative (separate inoculation) or 1:1 mixes of wild-type/mutant and mutant/complemented strain, both at $0.5 \times 10^{2} \mathrm{CFU}$ each (co-inoculation). CFU were enumerated after 2 days of incubation of the flowers at $20^{\circ} \mathrm{C}$ and $100 \%$ relative humidity. Values are the mean of five replicates containing two flowers each from one experiment. The experiment was repeated once with similar results.

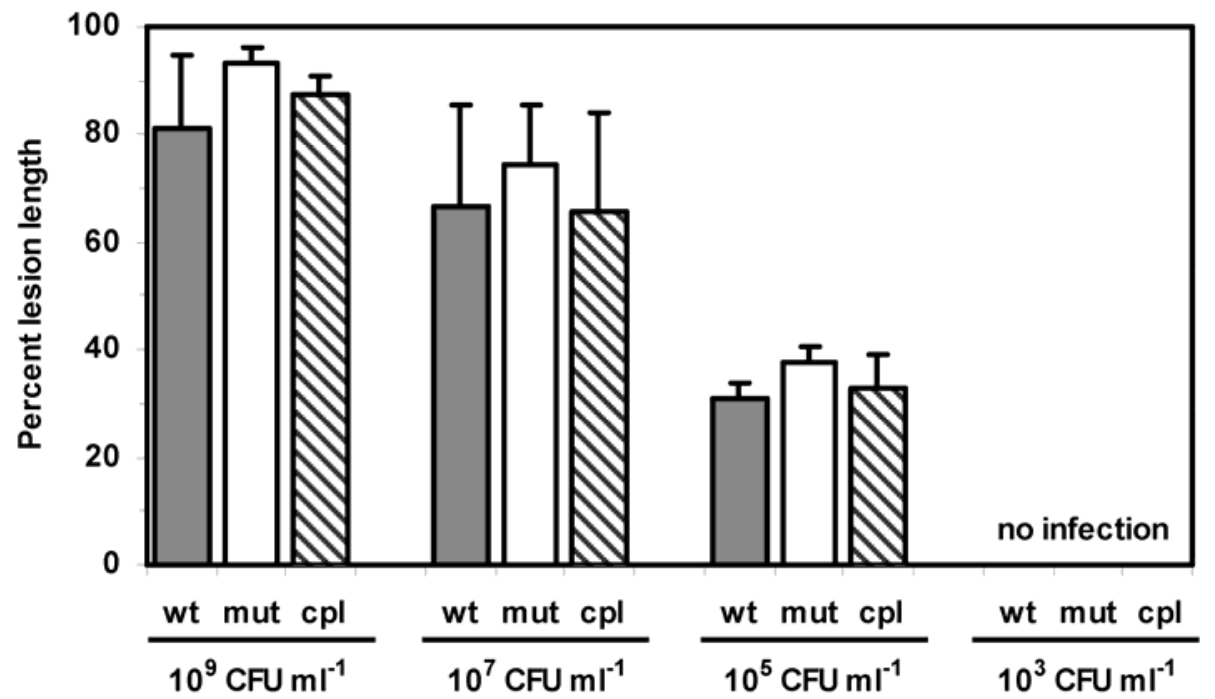

Fig. 6. Role of luxS in virulence of Erwinia amylovora FAW610 on 1-year-old grafted 'Golden Delicious' plants. Shoots were inoculated with bacterial suspensions containing approximately $10^{9}, 10^{7}, 10^{5}$, or $10^{3} \mathrm{CFU} \mathrm{ml}{ }^{-1}$ of a single strain derivative. Disease progress was measured after 14 days. Values for percent lesion length represent the means of three replicates with standard error bars. 
mutation reduces signal production due to pleiotrophic effects that result in the augmented use of the oxaloacetate pathway to compensate for the inability of the bacteria to generate SAM via the (AMC) (Sperandio et al. 2003).

Undeniably, cross-feeding assays using V. harveyi BB170 showed that both the wild type and the luxS-complemented derivative of either CFBP1430 and FAW610 were able to trigger a faint but clear response in the AI-2 reporter strain, and that this function was suppressed in the mutants (Table 1). These results can be explained by the fact that a background level of DPD (the natural AI-2 precursor) is produced as byproduct of the LuxS-mediated reaction that leads to detoxification of SAH by rescuing the homocysteine (HC) moiety from the AMC-cycle intermediate SRH. DPD is an unstable transitional molecule thought to be spontaneously converted into the active AI-2 molecule (i.e., furanosyl borate diester in Vibrionales) (Winzer et al. 2002) or $R$-THMF in Enterobacteriales (Miller at al. 2004). A recent report by Turovskiy and Chikindas (2006) demonstrates that the traditional BB170-based autoinducer-2 bioassay is a qualitative, not quantitative, method that may be influenced by the composition of the culture broth (e.g., by low or high glucose levels in the medium). Therefore, the apparent weak positive results obtained in the BB170 bioassay with wild-type and complemented strains, and its loss in the mutants, may simply reflect the functionality of LuxS in the AMC, and may not be indicative of the presence of a working quorum-sensing system so much as a metabolic phenomenon.

This hypothesis was confirmed by the means-of-cultivation experiments in which strain derivatives were grown in rich medium, in minimal medium with sufficient sulfur supplies, or in minimal medium under sulfur limitation. The resulting growth curves showed that $\operatorname{luxS}$ mutants were not impaired in LB or in DMM containing $8.4 \mathrm{mM} \mathrm{SO}_{4}^{-}$, but displayed significantly reduced growth when methionine was used as sole sulfur source already at a concentration as low as $100 \mu \mathrm{M}$. In order to obtain a comparable effect with cysteine, the concentration of the amino acid must be lowered to $10 \mu \mathrm{M}$, showing that the mutation in the luxS gene directly affects methionine metabolism. The decrease in absorbance displayed in the stationary phase by the mutant in DMM and in modified DMM with $50 \mu \mathrm{M}$ cysteine as sole sulfur source was consistent with a toxic effect generated by the accumulation of SAH (Pei and Zhu 2004) that results from the interruption of the AMC through by the
$\operatorname{luxS}$ mutation. It is noteworthy that phenotypes displaying reduced growth under sulfur-limiting conditions were not relieved when the $\operatorname{luxS}$ mutant was cultured together with a strain with unaffected $\operatorname{luxS}$ activity (i.e., the wild type or the complemented derivative). This suggests that the strains with an intact luxS gene were unable to complement the $\operatorname{luxS}$ mutation by the means of a purported AI-2 production and secretion. Thus, the observed growth pattern was not caused by an extracellular signal, but was likely of a metabolic, intracellular nature. This conclusion is strengthened by analogous results recently obtained using a similar approach in other luxS-positive bacteria, such as Staphylococcus aureus or Serratia plymuthica (Doherty et al. 2006; Van Houdt et al. 2006). An additional indication that, in Erwinia amylovora, luxS is involved in sulfur and amino acid metabolism is the position of the $\operatorname{luxS}$ open reading frame in the E. amylovora genome. Specifically, the gene is contiguous to and arranged in tandem with $g \operatorname{sh} A$, a $\gamma$-glutamylcystein synthetase that is involved in the metabolism of the other sulfur-containing amino acid, cysteine.

Further support for the metabolic role of luxS in E. amylovora was provided by the RNA expression profiling of selected AMC-related genes during growth in sulfur-limiting media. Upregulation of metE (HC methyltransferase), metK (SAM synthetase), and metR (activator of the AMC) was observed in luxS mutants under sulfur limitation, while $p f s$ (MTA/SAHase) and metJ (repressor of the AMC) were downregulated. This is indicative of a disturbance of the normal methionine pool in the cell caused by the interruption of the AMC following the inactivation of $\operatorname{lux} S$. Similarly, the slight decrease in environmental fitness observed in the mutant-specifically, reduced ability to colonize apple flowers-most probably was due to this metabolic imbalance, rather than to a disturbed quorumsensing system. An efficient methionine biosynthetic pathway previously was shown to be required for epiphytic fitness of plant-pathogenic bacteria (Andersen et al. 1998). The metabolic origin of this dysfunction, and the absence of an extracellular signal, is further suggested by the fact that, when the luxS mutant was coinoculated in apple flowers with a strain with luxS activity (i.e., the wild-type or the isogenic complemented strain), the mutant did not recover normal colonization ability. On the contrary, results obtained were even slightly more exaggerated when mutants were coinoculated with either the wild-type or complemented strains compared with the individ-

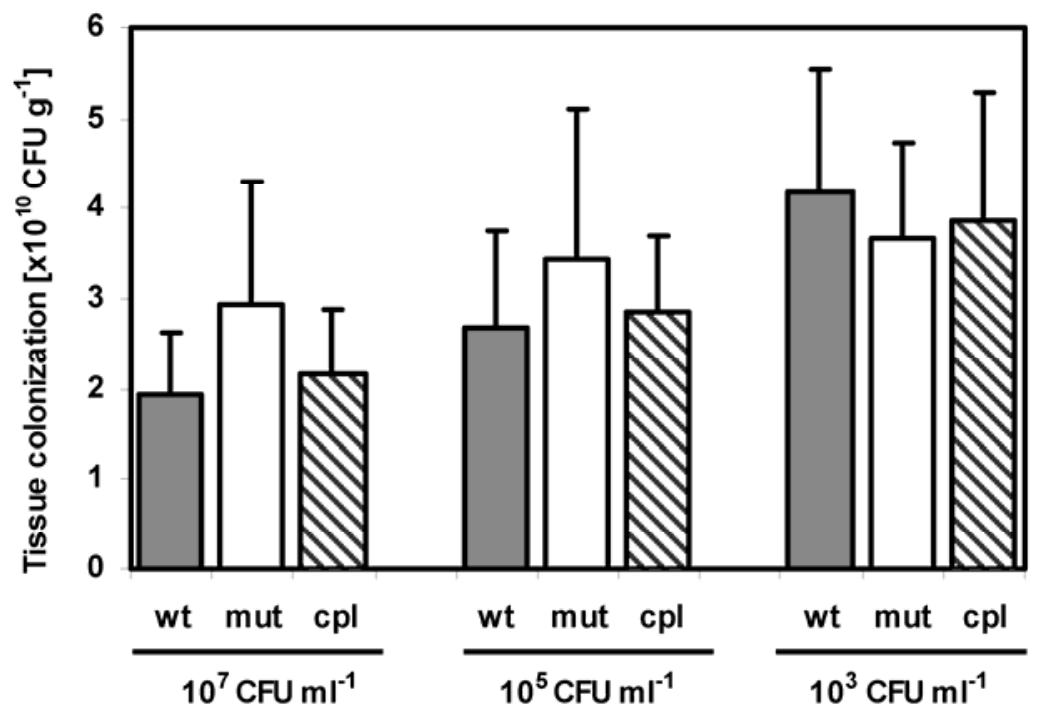

Fig. 7. Erwinia amylovora FAW610 colonization of immature pear tissue. Each fruit was inoculated in an artificial 1-mm-wide wound with $5 \mu$ l of a suspension containing approximately $10^{7}, 10^{5}$, or $10^{3} \mathrm{CFU} \mathrm{ml^{-1 }}$ of a single strain derivative. CFU were enumerated after 7 days of incubation of the infected fruit at $24^{\circ} \mathrm{C}$ in a humidified chamber. Values are the mean of three replicates and error bars represent standard deviations. 
ual inoculation of the strains, indicating an $\operatorname{luxS}$ role in competitiveness. Regardless of the molecular basis for reduced competitiveness, this observation points to $\operatorname{luxS}$ as a potential target for developing novel control approaches to reduce the ability of E. amylovora to establish in the primary fire blight infection court (Thomson 2000). Although we observed competition effects in flowers, which were inoculated with a relatively low concentration of bacteria in order to observe shifts in relative population size during growth, we have no indications that the role of $\operatorname{luxS}$ is dependent on bacterial concentration. In pear fruit colonization and virulence assays on apple plants, no difference was observed in the behavior of a luxS mutant and the wild type at any concentration between $10^{3}$ and $10^{9} \mathrm{CFU} \mathrm{m}^{-1}$ (Figs. 6 and 7).

Pathogenicity on apple plants, immature pear fruit, and other functions that normally are associated with AI-2-related quorum sensing in animal pathogens, such as swarming and motility, were essentially unaffected in the E. amylovora luxS mutants. A recent shot-gun screening approach to identify key virulence genes in E. amylovora also failed to identify luxS as a major determinant of virulence on pear fruit (Zhao et al. 2005). However, we found that two important virulence genes, $h r p L$ and $d s p A$, were downregulated in luxS mutants, suggesting a possible role for luxS at some stage in disease development. In Xanthomonas campestris pv. vesicatoria, hrp induction requires the presence of sulfur-containing amino acids (Schulte and Bonas 1992; Wengelnik and Bonas 1996); thus, efficient pathogenicity may depend on an unaltered sulfur metabolism. Although we observed no clear role on highly susceptible apple shoots, recent preliminary data suggests that host physiological status may affect the importance of luxS in virulence on apple and further studies are planned to examine the influence of environmental stimuli on $\operatorname{luxS}$. Both $h r p L$ and $d s p A$ are responsive to bacterial growth phase and environmental stimuli (Wei et al. 2000); thus, a role of $\operatorname{luxS}$ in virulence via metabolism under certain conditions cannot be discounted entirely.

In summary, the lack of known $\mathrm{AI}-2$ receptors in the $E$. amylovora genome, together with the failure of wild-type strains to chemically complement isogenic mutants in cocultivation experiments, strongly suggest that the role of $\operatorname{luxS}$ in the fire blight pathogen is of an intracellular metabolic nature and is not primarily related to AI-2 production or quorum sensing. Of course, the possibility that E. amylovora produces AI-2 to interfere with signaling of other bacteria or that the E. amylovora LuxS product is inadvertently utilized by other bacteria as an AI-2 signal cannot be ruled out completely.

\section{MATERIALS AND METHODS}

\section{Bacterial strains and culture media.}

Bacterial strains and plasmids used in this work are listed in Table 4. LB medium was used routinely for culturing E. amylovora, while autoinducer assay broth (AB) (Bassler et al. 1993 ) normally was used for $V$. harveyi bacterial growth. When necessary, the following antibiotics were added to the medium: ampicillin at $100 \mu \mathrm{g} \mathrm{ml}^{-1}$, kanamycin at $50 \mu \mathrm{g} \mathrm{ml}^{-1}\left(\mathrm{Km}^{50}\right)$, rifampicin at $100 \mu \mathrm{g} \mathrm{ml}^{-1}$ ( $\mathrm{Rif}^{100}$ ), and tetracycline at $50 \mu \mathrm{g} \mathrm{ml}^{-1}$ $\left(\mathrm{Tc}^{50}\right)$. E. amylovora AI-2 activity was assessed in LB, AB medium, hrp-inducing medium $(50 \mathrm{mM}$ potassium phosphate buffer, $7.6 \mathrm{mM}\left[\mathrm{NH}_{4}\right]_{2} \mathrm{SO}_{4}, 1.7 \mathrm{mM} \mathrm{MgCl}, 1.7 \mathrm{mM} \mathrm{NaCl}$, and $10 \mathrm{mM}$ glucose, $\mathrm{pH}$ 5.7) (Huynh et al. 1989) or DMM (55 mM potassium phosphate buffer, $7.6 \mathrm{mM}\left[\mathrm{NH}_{4}\right]_{2} \mathrm{SO}_{4}, 0.83 \mathrm{mM}$ $\mathrm{MgSO}_{4}, 1.7 \mathrm{mM}$ sodium citrate, and $6 \mathrm{mM}$ glucose, $\mathrm{pH}$ 7.0). A sulfur-free modification of the latter (sf-DMM) was used in cultivation and cocultivation experiments and was prepared by replacing $\mathrm{MgSO}_{4}$ and $\left(\mathrm{NH}_{4}\right)_{2} \mathrm{SO}_{4}$ with equal molar amounts of the corresponding chloride salts.

\section{PCR conditions.}

All PCRs described herein were performed either on DNA purified with the Promega Wizard DNA Extraction Kit (Promega Corp., Madison, WI, U.S.A.) or directly on bacterial lysates which were prepared as described by Rezzonico and associates (2003). Briefly, $5 \mu$ l of overnight LB culture was mixed with $95 \mu \mathrm{l}$ of lysis buffer (i.e., $50 \mathrm{mM} \mathrm{KCl} ; 10 \mathrm{mM}$ Tris- $\mathrm{HCl}$, $\mathrm{pH} 8.3$; and $0.1 \%$ Tween 20) and heated for $10 \mathrm{~min}$ at $99^{\circ} \mathrm{C}$ in a Techne TC-412 thermal cycler (Midsci, St. Louis). PCR amplification was carried out in $10-\mu \mathrm{l}$ reaction mixtures using $1 \mu \mathrm{l}$ of cell lysate or $1 \mu \mathrm{l}$ of purified DNA $(1 \mathrm{ng} / \mu \mathrm{l})$ and $0.4 \mathrm{mM}$ each primer in a final concentration of $1 \times$ master mix of the HotStarTaq MasterMix Kit (Qiagen, Basel, Switzerland). Cycling conditions were substantially the same throughout this work, with an initial denaturation and activation of the HotStarTaq enzyme for $15 \mathrm{~min}$ at $95^{\circ} \mathrm{C}$; followed by 35 cycles of $45 \mathrm{~s}$ of denaturation at $95^{\circ} \mathrm{C}, 45 \mathrm{~s}$ of annealing at $55^{\circ} \mathrm{C}$, plus $30 \mathrm{~s}$ of elongation for every $500 \mathrm{bp}$ of expected amplicon size; and a final elongation for $10 \mathrm{~min}$ at $72^{\circ} \mathrm{C}$. Primers used for PCR and RT-PCR were designed based on the genome sequence of $E$. amylovora Ea273 using a Web-based primer-picking program Primer3 (Rozen and Skaletsky 2000) and are listed in Table 5.

\section{Sequence analysis \\ of luxS and related genes in E. amylovora strains.}

Primers corBtoluxS and gshAtoluxS were used as described above to amplify an 843-bp fragment spanning from $\operatorname{cor} B$ to $g s h A$ in a collection of E. amylovora strains of worldwide origin (Table 4). PCR amplicons were purified from PCR mix by washing twice with $100 \mu \mathrm{l}$ of double-distilled water $\left(\mathrm{ddH}_{2} \mathrm{O}\right)$ on a MultiScreen PCR Plate (Millipore, Molsheim, France), resuspended in $30 \mu \mathrm{l}$ of $\mathrm{ddH}_{2} \mathrm{O}$, and visually quantified in agarose gel. The cycle-sequencing reaction was performed with 20 to $40 \mathrm{ng}$ of purified PCR product using the ABI PRISM BigDye Terminators v3.1 Cycle Sequencing Kit (Applied Biosystems, Foster City, CA, U.S.A.) according to the manufacturer's instructions using primers corBtoluxS and gshAtoluxS, each at a final concentration of $0.2 \mu \mathrm{M}$. Cyclesequencing products were cleaned through water-swelled Sephadex G-50 columns (Amersham Biosciences, Uppsala, Sweden) on MultiScreen HV plates (Millipore) and sequenced on an ABI PRISM 3100 Genetic Analyzer. Obtained sequences were assembled using the Sequencher software (version 4.0.5; Gene Codes Corporation, Ann Arbor, MI, U.S.A.). For phylogenetic inference, representative luxS sequences of $E$. amylovora were aligned with luxS sequences of other gram-negative and gram-positive bacteria using the web-based program ClustalW (Thompson at al. 1994). Sites presenting alignment gaps were excluded from analysis. The Molecular Evolutionary Genetics Analysis program, version 2.1 (Kumar et al. 2001), was used to calculate evolutionary distances and to infer trees based on the neighbor-joining method with the Jukes-Cantor formula. Nodal robustness of the inferred trees was assessed by 1,000 bootstrap replicates. The presence of known AI-2 receptor genes was verified by comparing their published DNA sequences using BLAST with the translation of the completed genome of E. amylovora Ea273. Sequences used were lux $P Q$ of $V$. harveyi BB7 (accession number U07069), lsr-operon genes of Salmonella enterica subsp. enterica serovar Typhi Ty2 (AE014613), and mqsR of Escherichia coli K12 (U00096).

\section{Construction of plasmid pCAM-A $\Omega$ B2 carrying luxS interrupted by an $\Omega$ cassette.}

The flanking regions of luxS were amplified using primer pairs EcorEB-fw and BluxS-rD, yielding a 1,069-bp amplicon (fragment B2) containing the C-terminal regions of luxS and $\operatorname{cor} B$, and BluxS-fD and EgshA-rev, yielding a 1,058-bp am- 
plicon (fragment A) containing the $\mathrm{N}$-terminal region of luxS and the C-terminal region of $g s h A$ plus the intergenic region bearing the $\operatorname{luxS}$ promoter. Both fragments were digested with restriction enzyme Bam $\mathrm{HI}$ and ligated together using T4 ligase. The 2,119-bp band corresponding to the AB2 ligation was isolated on agarose, reamplified with EcorEB-fw and EgshA-rev, and digested with EcoRI. Plasmid pCAM-MCS (Burse et al. 2004) was linearized with EcoRI, dephosphorylated with shrimp alkaline phosphatase (SAP), and then ligated with the EcoRI-digested AB fragment. Ligation was transformed into chemically competent $E$. coli $\mathrm{S} 17-1 \lambda$ pir cells using standard transformation procedures (Sambrook et al. 1989) and transformants were selected using $\mathrm{Tc}^{50}$ selection. The presence of the AB2 fragment was verified by PCR amplification of a 408bp amplicon using primers corBtoluxS and gshAtoluxS. The resulting plasmid, named pCAM-AB2, was extracted from $E$. coli using the QIAGEN Miniprep kit, linearized with BamHI, and dephosphorylated with SAP. The $\Omega$ cassette, containing a kanamycin-resistance determinant, was amplified from plasmid
pHP45 $\Omega$ Km (Prentki and Krisch 1984) using primers B $\Omega$-fw and $\mathrm{B} \Omega$-rev. The PCR product was digested with $\mathrm{BamHI}$ and ligated with the linearized pCAM-AB2 plasmid using T4 ligase. Ligation was transformed into competent $E$. coli $\mathrm{S} 17-1$ $\lambda$ pir cells as described above and transformants containing the $\Omega$ cassette were selected on $\mathrm{LB}-\mathrm{Km}^{50}$. The correct insertion of the cassette was verified by PCR amplification of the 2,377-bp $\mathrm{A} \Omega \mathrm{B} 2$-amplicon using primers corBtoluxS and gshAtoluxS, and the resulting plasmid was named pCAM-A $\Omega B 2$.

\section{luxS gene disruption by allelic exchange in Erwinia amylovora strains CFBP1430 and FAW610.}

Plasmid pCAM-A $\Omega$ B2 is a suicide vector for members of Enterobacteriaceae because it bears the R6K origin of replication and can be maintained only in host strains, such as EScherichia coli $\mathrm{S} 17-1 \lambda$ pir, producing the R6K-specified protein $\pi$. Furthermore, E. coli S17-1 $\lambda$ pir contains the $\lambda$ pir gene. This strain has chromosomally integrated conjugal transfer functions (RP4 transfer functions); therefore, when it is used as a spe-

Table 4. Bacterial strains and plasmids used in this work

\begin{tabular}{|c|c|c|c|}
\hline Strain or plasmid & Geographic origin (year) & Plant origin, relevant characteristics ${ }^{\mathrm{a}}$ & Reference $^{b}$ \\
\hline \multicolumn{4}{|l|}{ Erwinia amylovora strains } \\
\hline CFBP1232 & United Kingdom (1959) & Pyrus communis & Jock et al. 2002 \\
\hline CFBP1430 & Lille, France (1972) & Crataegus sp. & Jock et al. 2002 \\
\hline BPIC847 & Arcadia, Greece (1984) & P. communis & Zhang et al. 1998 \\
\hline JL1185 & Washington, U.S.A. (1988) & P. communis & Loper et al. 1991 \\
\hline 01SFR-BO & Ravenna, Italy (1991) & Sorbus sp. & Jock et al. 2002 \\
\hline $\mathrm{Ea} 02$ & Vollèges, Switzerland (2002) & Cotoneaster sp. & Molina et al. 2005 \\
\hline Ea153 & Oregon, U.S.A. (1989) & Malus domestica & Johnson et al. 1993 \\
\hline Ea1/79 & Germany (1979) & Cotoneaster sp. & Jock et al. 2002 \\
\hline Ea263 & Baden-Wüttenberg, Germany (1996) & M. domestica & Jock et al. 2002 \\
\hline Ea273 & New York, U.S.A. (1971) & M. domestica & Beer et al. 1991 \\
\hline Ea321 [CFBP1367] & Angers, France (unknown) & Crataegus sp. & Beer et al. 1991 \\
\hline OMP-BO 379 & Emilia Romagna, Italy (2001) & P. communis & A. Calzolari (PC) \\
\hline Ea4/82 & Egypt (1982) & P. communis & Jock et al. 2002 \\
\hline FAW610 [ACW24849] & Appenzell, Switzerland (2001) & M. domestica & J. Vogelsanger (PC) \\
\hline FAW611 [ACW26599] & Switzerland (2001) & Cydonia sp. (Quince) & J. Vogelsanger (PC) \\
\hline OPM-BO 691.2 & Emilia Romagna, Italy (1995) & P. communis & Zhang et al. 1998 \\
\hline IPV-BO 1077/7 & Emilia Romagna, Italy (1994) & P. communis & Babini and Mazzucchi 2000 \\
\hline IPV-BO 5010 & Lombardia, Italy (2003) & P. communis & Venturi et al. 2004 \\
\hline IPV-BO 5011 & Lombardia, Italy (2003) & P. communis & Venturi et al. 2004 \\
\hline IPV-BO 5039 & Friuli Venezia Giulia, Italy (2003) & Crataegus sp. & Venturi et al. 2004 \\
\hline IPV-BO 5357 & Piemonte, Italy (2003) & Cotoneaster sp. & Venturi et al. 2004 \\
\hline \multicolumn{4}{|l|}{ Other Erwinia strains } \\
\hline E. billingiae LMG 2613 & United Kingdom (1959) & P. communis & Mergaert et al. 1999 \\
\hline \multicolumn{4}{|l|}{ E. amylovora derivatives } \\
\hline CFBP1430 $\Delta$ luxS & $\ldots$ & $\mathrm{Km}^{\mathrm{r}}$, lux $S$ interrupted by the $\Omega$ cassette of $\mathrm{pHP} 45 \Omega \mathrm{Km}$ & This work \\
\hline CFBP1430 ++ & $\ldots$ & $\mathrm{Km}^{\mathrm{r}}, \mathrm{Tc}^{\mathrm{r}}, \mathrm{CFBP} 1430 \Delta l u x S$ complemented by pMF8805 & This work \\
\hline FAW610 1 lux $S$ & $\ldots$ & $\mathrm{Km}^{\mathrm{r}}$, luxS interrupted by the $\Omega$ cassette of $\mathrm{pHP} 45 \Omega \mathrm{Km}$ & This work \\
\hline FAW610 $4+$ & $\ldots$ & $\mathrm{Km}^{\mathrm{r}}, \mathrm{Tc}^{\mathrm{r}}$, FAW610 1 luxS complemented by pMF8805 & This work \\
\hline \multicolumn{4}{|l|}{ Escherichia coli strains } \\
\hline S17-1 $\lambda$ pir & $\ldots$ & $\begin{array}{l}\text { recA thi pro } h s d R\left[\mathrm{res}^{-} \bmod ^{+}\right][\mathrm{RP} 4:: 2-\mathrm{Tc}:: \mathrm{Mu}-\mathrm{Km}:: \mathrm{Tn} 7] \\
\lambda \text { pir phage lysogen }\end{array}$ & Simon et al. 1983 \\
\hline TOP10 & $\ldots$ & 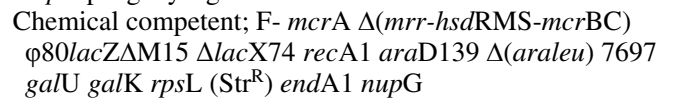 & Invitrogen \\
\hline \multicolumn{4}{|l|}{ Vibrio harveyi strains } \\
\hline BB120/ATCC BBA-1116 & $\ldots$ & Wild type, $\mathrm{AI}-1^{+} \mathrm{AI}-2^{+}$, sensor- $1^{+}$sensor $-2^{+}$ & Bassler et al. 1997 \\
\hline BB170/ATCC BBA-1117 & $\ldots$ & $\mathrm{AI}-1^{+} \mathrm{AI}-2^{+}$, sensor- $1^{-}$sensor- $2^{+}$ & Bassler et al. 1993 \\
\hline \multicolumn{4}{|l|}{ Plasmids } \\
\hline $\mathrm{pHP} 45 \Omega \mathrm{Km}$ & $\ldots$ & $\mathrm{Amp}^{\mathrm{r}}, \mathrm{Km}^{\mathrm{r}}$, pHP45 containing the $\mathrm{Km}^{\mathrm{r}}$ cassette & Prentki and Krisch, 1984 \\
\hline pCAM-MCS & $\ldots$ & $A m p^{r}$, cloning vector & Burse et al. 2004 \\
\hline pCAM-AB2 & $\ldots$ & $\begin{array}{l}\text { Amp }{ }^{\mathrm{r}}, 2.1-\mathrm{kb} \text { fragment containing the flanking regions of } \\
\text { luxS cloned into EcoRI site of pCAM-MCS }\end{array}$ & This work \\
\hline $\mathrm{pCAM}-\mathrm{A} \Omega \mathrm{B} 2$ & $\ldots$ & $\begin{array}{l}\mathrm{Amp}^{\mathrm{r}}, \mathrm{Km}^{\mathrm{r}}, \Omega \text { cassette from pHP } 45 \Omega \text { cloned into BamHI } \\
\text { site of pCAM-AB2 }\end{array}$ & This work \\
\hline pME3088 & $\ldots$ & $\mathrm{Tc}^{\mathrm{r}}$, cloning vector & Voisard et al. 1994 \\
\hline pMF8805 & $\ldots$ & $\begin{array}{l}\mathrm{Tc}^{\mathrm{r}}, 1.1-\mathrm{kb} \text { fragment containing luxS cloned into EcoRI } \\
\text { site of pME3088 }\end{array}$ & This work \\
\hline
\end{tabular}

\footnotetext{
${ }^{\mathrm{a}} \mathrm{Km}^{\mathrm{r}}, \mathrm{Tc}^{\mathrm{r}}, \mathrm{Amp}^{\mathrm{r}}$, and $\mathrm{Str}^{\mathrm{r}}=$ resistant to kanamycin, tetracycline, ampicillin, and streptomycin, respectively.
}

${ }^{\mathrm{b}} \mathrm{PC}=$ personal communication and Invitrogen, Basel, Switzerland. 
cific host strain into which the transposon vector DNA is transformed, the transfer occurs by means of a biparental mating and a helper strain is not necessary. Overnight cultures $(5 \mathrm{ml})$ of E. coli S17-1 $\lambda$ pir/pCAM-A $\Omega$ B2 in LB- $\mathrm{Km}^{50}$ and 3-dayold, late-stationary-phase cultures of rifampicin-resistant $\mathrm{Er}$ winia amylovora in LB-Rif ${ }^{100}$ were pelleted by centrifugation, washed twice with fresh LB, mixed together in a 3:1 ratio, and then resuspended in $20 \mu \mathrm{l}$ of LB before being finally spotted in the center of LB plates. Plates were incubated at $37^{\circ} \mathrm{C}$ for 2,5 , and $7.5 \mathrm{~h}$; then, the cells were eluted with $300 \mu \mathrm{l}$ of LB medium and plated on LB agar supplemented with rifampicin $\left(100 \mu \mathrm{g} \mathrm{ml}^{-1}\right)$ and kanamycin $\left(50 \mu \mathrm{g} \mathrm{ml}^{-1}\right)$ to select for transformed E. amylovora. Plates were incubated overnight at $28^{\circ} \mathrm{C}$ and the resulting colonies were analyzed. To exclude mutants that resulted from single crossover events (i.e., plasmid integration in the chromosome), kanamycin-resistant colonies were transferred in parallel onto Chromocult coliform agar (Merck,
Dietikon, Switzerland) supplemented with kanamycin (50 $\mu \mathrm{g}$ $\mathrm{ml}^{-1}$ ) and onto LB agar plates supplemented with ampicillin $\left(100 \mu \mathrm{g} \mathrm{ml}^{-1}\right)$. Kanamycin-resistant and ampicillin-sensitive colonies with the distinctive E. amylovora pink coloration on Chromocult agar were selected and allelic exchange was verified by PCR using primer-pair combinations corBext1/ agemO and gshAext/Omega.

\section{Complementation of $\boldsymbol{E}$. amylovora mutant strains

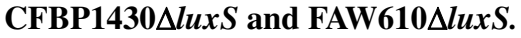

Primers EcorB-fw and EgshA-rD were used to amplify a 1,124-bp fragment containing the $\operatorname{luxS}$ gene and its promoter plus the C-terminal regions of the flanking genes $\operatorname{cor} B$ and gshA ("Fragment bSa"). Plasmid pME3088 (Voisard et al. 1994), bearing a tetracycline-resistance determinant, was linearized with EcoRI, dephosphorylated with SAP, and then ligated with the EcoRI-digested bSa-fragment. Ligation was trans-

Table 5. Primers used in this work

\begin{tabular}{|c|c|c|c|}
\hline Primer $^{a}$ & Sequence $5^{\prime}-3^{\prime b}$ & Utilization, target gene function & Reference \\
\hline \multicolumn{4}{|l|}{ Mutant } \\
\hline EcorEB-fw & CCACGAATTCAGTACTGCCGAAAACCGTTG & Amplification of fragment B2 & This work \\
\hline BluxS-rD & CCACGGATCCCACTGCCAAAAGAGAAGCTG & Amplification of fragment B2 & This work \\
\hline BluxS-fD & CCACGGATCCTGGTGTGATCGACGGTAAAG & Amplification of fragment $\mathrm{A}$ & This work \\
\hline EgshA-rev & CCACGGATCCGCGATCTTGGCTACACCAAT & Amplification of fragment A & This work \\
\hline EcorB-fw & CCACGAATTCGCCTGGTCACCATTGAAGAT & Amplification of fragment bSa & This work \\
\hline EgshA-rD & CCACGAATTCCGAAGCCTTTTTACAAAGCAA & Amplification of fragment bSa & This work \\
\hline $\mathrm{B} \Omega-\mathrm{fw}$ & CCACGGATCCCAATTCCCCTGCTCGCGCAGG & Amplification of $\Omega$-cassette & This work \\
\hline $\mathrm{B} \Omega$-rev & CCACGGATCCCAGCTTAGTAAAGCCCTCGCT & Amplification of $\Omega$-cassette & This work \\
\hline corBtoluxS & GATTAAGCAGGTGCGCATTA & Verification of fragments $\mathrm{AB} 2$ and $\mathrm{A} \Omega \mathrm{B} 2$ & This work \\
\hline gshAtoluxS & AAGTGATACGCTTAGCTTCG & Verification of fragments $\mathrm{AB} 2$ and $\mathrm{A} \Omega \mathrm{B} 2$ & This work \\
\hline corBext 1 & TTACAAGCTGCGTCATCAGG & Verification of allelic exchange & This work \\
\hline agemO & ACTGTGGGTCAAGGATCTGG & Verification of allelic exchange & This work \\
\hline gshAext & GGTTGGGTGATCCCTTACCT & Verification of allelic exchange & This work \\
\hline Omega & CACCAAGGTAGTCGGCAAAT & Verification of allelic exchange & This work \\
\hline luxSic1 & GGCATTCACACGCTGGA & Detection of $\operatorname{lux} S$ & T. Paternoster \\
\hline luxSic2 & CATCGCCGCRTTCCACGC & Detection of $\operatorname{lux} S$ & T. Paternoster \\
\hline \multicolumn{4}{|l|}{ RT-PCR } \\
\hline RTluxS-fw & CTTTACCGTCGATCACACCA & $\begin{array}{l}\text { Amplification of 420-bp luxS amplicon, methionine } \\
\text { metabolism/AI-2 signal }\end{array}$ & This work \\
\hline RTluxS-rev & ATATGACGGGCGATATCCTG & & This work \\
\hline RT16S-fw & CAGAAGAAGCACCGGCTAAC & Amplification of 342-bp rrs amplicon, 16S rDNA synthesis & This work \\
\hline RT16S-rev & AAACGATGTCGACTTGGAGG & & This work \\
\hline RThrpL-fw & CGATGGGCTACCGCTTAATA & $\begin{array}{l}\text { Amplification of 431-bp } h r p L \text { amplicon, } \sigma \text {-factor, control of } h r p \\
\text { gene expression }\end{array}$ & This work \\
\hline RThrpL-rev & TCAAATGTGCTGCAATAGCC & & This work \\
\hline RTdspA-fw & AAAACCGCACTGACCAAATC & Amplification of 451-bp $d s p A$ amplicon, virulence effector & This work \\
\hline RTdspA-rev & CTGGCACCTTCTTGCTAAGG & & This work \\
\hline RTgalE-fw & CGATGACGTGGTGATACTGG & $\begin{array}{l}\text { Amplification of 495-bp galE amplicon, UDP-glucose 4- } \\
\text { epimerase }\end{array}$ & This work \\
\hline RTgalE-rev & ATCTGACCGGATTCATGAGC & & This work \\
\hline RTmetE-fw & TCAGATTGATGAGCCTGCAC & $\begin{array}{l}\text { Amplification of 304-bp metE amplicon, homocysteine } \\
\text { transmethylase }\end{array}$ & This work \\
\hline RTmetE-rev & ACGATATCCACTCGCCAAAC & & This work \\
\hline RTmetJ-fw & CTGAATGGAACGGCGAATA & $\begin{array}{l}\text { Amplification of 275-bp metJ amplicon, transcriptional } \\
\text { repressor of met genes }\end{array}$ & This work \\
\hline RTmetJ-rev & AAGAGGCAAAAGCGATCATG & & This work \\
\hline RTmetK-fw & GCTTTGATGCCAATTCCTGT & $\begin{array}{l}\text { Amplification of 326-bp met } K \text { amplicon, } S \text {-adenosylmethionine } \\
\text { synthetase }\end{array}$ & This work \\
\hline RTmetK-rev & TGTCTACTCAACACGCCGAG & & This work \\
\hline RTmetR-fw & TATTGCCGCAGATACAGCAG & $\begin{array}{l}\text { Amplification of 339-bp metR amplicon, transcriptional } \\
\text { activator of met genes }\end{array}$ & This work \\
\hline RTmetR-rev & TATCTCACCCCAGGATCTCG & & This work \\
\hline RTpfs-fw & GAAGTTGCCCTGCTGAAATC & Amplification of 338-bp pfs amplicon, MTA/SAH nucleosidase & This work \\
\hline RTpfs-rev & GGTGATGCCTTTATCAACGG & & This work \\
\hline RTscrK-fw & ACGCCACTTCACCTTTATGG & Amplification of 271-bp scrK amplicon, fructokinase & This work \\
\hline RTscrK-rev & GATGATGTCTGCCAGCTCAA & & This work \\
\hline RTsrlD-fw & TGGCAGCAAGCATAACTCTG & $\begin{array}{l}\text { Amplification of 284-bp srlD amplicon, sorbitol-6-phosphate } \\
\text { dehydrogenase }\end{array}$ & This work \\
\hline RTsrlD-rev & TGTCACTCGCGTAAAACAGC & & This work \\
\hline
\end{tabular}

\footnotetext{
${ }^{\mathrm{a}}$ Mutant $=$ mutant construction and verification and RT-PCR $=$ reverse-transcription polymerase chain reaction .

${ }^{\mathrm{b}}$ Sequences in bold are the recognition sites for the restriction enzymes.
} 
formed into competent TOP10 Escherichia coli cells (Invitrogen) according to the manufacturer's instructions. The insertion of the bSa-fragment was verified in the transformed colonies ( $\mathrm{Tc}^{50}$ selection) by PCR, again using EcorB-fw and EgshA-rD. The plasmid bearing the intact luxS gene, named pMF8805, was extracted from E. coli using the QIAGEN Miniprep kit and transformed by electroporation $(12.5 \mathrm{~V} / \mathrm{cm}, 25 \mu \mathrm{F}, 200 \Omega)$ into competent Erwinia amylovora CFBP1430 and FAW610 $\Delta l u x S$ mutant strains. Verification of $\operatorname{luxS}$ expression in CFBP1430 and FAW610 wild-type, mutant, and complemented strains was assessed by RT-PCR using the primers RTluxS-fw and RTluxS-rev and PCR conditions described below, but using an annealing temperature of $60^{\circ} \mathrm{C}$ and 40 cycles of PCR.

\section{Detection of AI-2 production in E. amylovora using $V$. harveyi reporter strain BB170.}

Stimulation of light production in $V$. harveyi reporter strain BB170 (sensor $1^{-}$sensor $2^{+}$) by E. amylovora was assessed as described by Surette and Bassler (1998). BB170 was grown overnight at $30^{\circ} \mathrm{C}$ in $\mathrm{AB}$ medium (Greenberg et al. 1979) to an optical density at $600 \mathrm{~nm}\left(\mathrm{OD}_{600}\right)$ of approximately 1.0. The culture was diluted 1:5000 in fresh medium and cell-free culture fluids from E. amylovora were added at $10 \%$ final concentration. The resulting light production was monitored with a Fluoroskan Ascent FL luminometer (Thermo Labsystem, Helsinki, Finland). The maximal stimulation of light production occurred at $4 \mathrm{~h}$ after dilution and addition of the culture fluids. All experiments were performed at least three times. The stimulation of light production obtained from BB120 wildtype strain cell culture fluid in $\mathrm{AB}$ medium was considered to be $100 \%$ and the results were considered positive when the stimulation of light was, in all three experiments, higher than $10 \%$ of the result obtained for BB120 (Bassler et al. 1997).

\section{Growth under sulfur-limiting conditions in vitro.}

The growth ability of E. amylovora under sulfur-limiting conditions was studied using $200-\mu 1$ microcultures in 100 -well honeycomb plates (well volume $400 \mu \mathrm{l}$ ) at $28^{\circ} \mathrm{C}$ with regular shaking at 15-min intervals. FAW610 wild type, the mutant

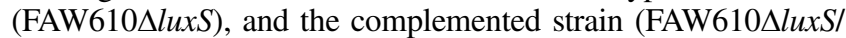
pMF8805) were grown overnight in separate cultures on DMM, collected by centrifugation, and washed twice with sterile $0.9 \% \mathrm{NaCl}$. All strains were inoculated at an initial $\mathrm{OD}_{600}=$ 0.018 on $\mathrm{LB}, \mathrm{DMM}$ (total $\mathrm{SO}_{4}$ molarity $=8.4 \mathrm{mM}$ ), or modified sf-DMM either with methionine or cysteine $(10,50$, or $100 \mu \mathrm{M})$ as sole sulfur sources. Growth curves were measured in quadruplicate by periodically quantifying the absorbance through a 420- to 580-nm wide band filter using a Bioscreen C MBR system (Growth Curves Oy, Helsinki, Finland).

\section{Competition assay under sulfur-limiting conditions.}

For competition experiments, FAW610 and FAW610 $l u x S$ or FAW610 and FAW610 $l u x S /$ pMF8805 were coinoculated in a $1: 1$ ratio at the same total $\mathrm{OD}_{600}=0.018$ for each individual culture (corresponding to approximately $2 \times 10^{7} \mathrm{CFU} \mathrm{ml} \mathrm{m}^{-1}$ ) in $10 \mathrm{ml}$ of DMM or modified sf-DMM with $100 \mu \mathrm{M}$ methionine. Separate cultures of single-strain derivatives were used as controls. The bacteria were sampled after 7, 22, 31, and $53 \mathrm{~h}$ of growth at $28^{\circ} \mathrm{C}$ and $220 \mathrm{rpm}$, and viable counts were performed by serial dilutions on selective $\left(\mathrm{LB}-\mathrm{Km}^{50}\right.$ and LB-Tc ${ }^{50}$ for mutant and complemented strain, respectively) and nonselective LB agar (total bacteria), enabling subtractive determination of the wild-type population.

\section{Genetic expression in luxS mutants.}

Genetic expression in E. amylovora strains was evaluated by monitoring the production of gene-specific mRNAs by semi- quantitative RT-PCR in DMM and in modified DMM with 100 $\mu \mathrm{M}$ methionine as sole sulfur source. Primers used for RTPCR are listed in Table 5. The expression of following genes was monitored: luxS (methionine metabolism/putative AI-2 signal production); pathogenicity-related genes hrpL (alternative $\sigma$-factor for type III secretion system genes) and $d s p A$ (secreted avirulence protein); sorbitol metabolism gene $s r l D$ (sorbitol-6-phosphate dehydrogenase); galactose metabolism gene galE (UDP-glucose 4-epimerase); fructose metabolism gene $s c r K$ (fructokinase); and AMC genes metE (homocysteine transmethylase), metK ( $S$-adenosylmethionine synthetase), metJ (transcriptional repressor of met genes), metR (transcriptional activator of met genes), and $p f s$ (5'-methylthioadenosine/ $S$-adenosylhomocysteine nucleosidase). RNA extraction was performed from E. amylovora cells using the RNeasy mini kit (Qiagen) at three different sampling times: $16 \mathrm{~h}$ (middle of exponential growth phase), $26 \mathrm{~h}$ (end of exponential growth phase), and $40 \mathrm{~h}$ (stationary phase). Reverse transcription was conducted using the QuantiTect Reverse Transcription kit (Qiagen) and $400 \mathrm{ng}$ of total RNA per reaction. After the reverse transcription reaction, cDNA was purified through QIAquick PCR purification columns (Qiagen), and the cDNA quantity was measured spectrophotometrically and adjusted in each

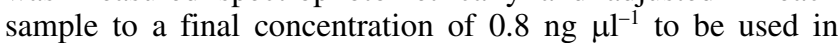
PCR amplification. A constitutive $r r s$ gene encoding for $16 \mathrm{~S}$ rRNA was used as internal control for sample normalization. To ensure proper semiquantitative results, the PCR on cDNA was performed as described above, but the number of PCR cycles was adjusted individually for each primer pair in order to fall in the exponential phase of the amplification reaction (Walther et al. 1998); therefore, the relative expression values are comparable only within each individual gene, not among the different genes.

\section{Motility and biofilm assays.}

Motility assays were performed with E. amylovora CFBP1430 and FAW610 strains and derivatives on LB plates containing decreasing $(0.8,0.5$, and $0.3 \%)$, concentration of agar as described (Dixit et al. 2002). Briefly, for every strain, 1 $\mu \mathrm{l}$ of LB overnight cultures of wild-type, mutant, and complemented strains was spotted on the same plate and grown for 48 $\mathrm{h}$ at $23^{\circ} \mathrm{C}$. The diameters of the three visible chemotactic rings were measured. Average values and standard deviations $(n=6)$ were calculated. Both strains were further tested for biofilm formation in rich medium as described by Yap and associates (2005) using LB, SOBG or SOCG medium. A 10- $\mu$ l aliquot of an overnight bacterial culture was suspended in $10 \mathrm{ml}$ of liquid medium and cultures were incubated at 24 or $30^{\circ} \mathrm{C}$ in stationary reaction tubes for up to 2 weeks. The formation of a biofilm around the edge of the culture tube was evaluated qualitatively by estimating the thickness of the bacterial layer at the air-liquid surface interface.

\section{Colonization of detached apple blossoms.}

Detached flower assays were performed following Pusey (2000) using newly opened Golden Delicious apple flowers of similar age collected in an orchard of the ACW in Wädenswil. Each detached flower was maintained with the cut peduncle submerged in $10 \%$ sterile sucrose solution in isolated indentations in sterile trays. Overnight bacterial cultures in LB were washed twice in $0.9 \% \mathrm{NaCl}$ solution and diluted in phosphatebuffered saline (PBS) to a final cell concentration of $10^{4} \mathrm{CFU}$ $\mathrm{ml}^{-1}$. Application of bacteria to flowers was achieved by touching each hypanthium with a 10- $\mu$ l droplet of the suspension. Flowers were enclosed in plastic boxes with moist paper towels to maintain near $100 \%$ relative humidity and then incubated for 2 days at $20^{\circ} \mathrm{C}$. After incubation, 10 flowers per treatment 
were sampled to determine bacterial population sizes. Two stigmas and a portion of the supporting style were placed in sterile microcentrifuge tubes containing $900 \mu \mathrm{l}$ of sterile PBS. Tubes were vortexed briefly and placed in a sonication bath for $30 \mathrm{~s}$. Samples were vortexed again and serial dilutions in 10fold dilution steps were spread on nutrient sucrose agar (NSA)Rif. Bacterial colonies were counted after 2 days of incubation at $28^{\circ} \mathrm{C}$. To evaluate competitiveness in apple blossoms, wildtype and mutant as well as mutant and complemented strains were applied on the flowers in a 1:1 mix. Each strain was used at half concentration with respect to the experiment featuring the single strains. The experiment was repeated once.

\section{Virulence assay on young apple trees.}

Virulence on young apple trees was evaluated using the standard assay of internal bacterial movement (Momol et al. 1998) and fire blight resistance (Khan et al. 2006), with slight modifications. Shoots of 15 to $30 \mathrm{~cm}$ in length of potted 1year-old grafted Golden Delicious plants were inoculated in a quarantine greenhouse with bacterial suspensions adjusted to cell densities of $10^{9}, 10^{7}, 10^{5}$, and $10^{3} \mathrm{CFU} \mathrm{ml}{ }^{-1}$. Shoot tips of trees were inoculated by inserting a $0.46-\mathrm{mm}$-diameter (26gauge) hypodermic needle through the stem just above the youngest opened leaf. Sufficient inoculum was introduced to fill the wound, leaving drops at each end of the wounds when the needle was removed. After 14 days, disease progress was measured as the percentage of total shoot length with observable lesion formation starting from the inoculation point, following Momol and associates (1998). The experiment was repeated once with three replicate plants in each trial.

\section{Virulence assay on immature pear fruit.}

Virulence on immature pear fruit was evaluated by inoculating the fruit with $5 \mu \mathrm{l}$ of bacterial suspensions adjusted to cell

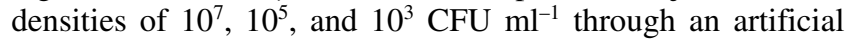
lesion produced using a 1-mm sterile steel tip (Zhao et al. 2005) after surface sterilization with $10 \%$ bleach solution. Four randomly chosen, immature pear fruit (Pyrus communis) of similar size were inoculated for each treatment using bacterial strain FAW610 and derivatives. After 1 week of incubation in a humidified chamber at $24^{\circ} \mathrm{C}$, the progress of the disease was recorded. The virulence of the strain derivatives was analyzed by measuring the diameter of the lesion on the fruit. For bacterial population studies, the inoculation site was excised using a no. 4 cork borer and homogenized in $0.5 \mathrm{ml}$ of $1 \times$ PBS. Serial dilutions in 10-fold dilution steps were spread on NSA-Rif. After 2 days of incubation at $28^{\circ} \mathrm{C}$, bacterial colonies in the appropriate dilution were counted and the number of cultivable cells per gram of pear tissue was calculated. The experiment was repeated once.

\section{ACKNOWLEDGMENTS}

This research was supported by SafeCrop Centre, funded by Fondo per la Ricerca, Autonomous Province of Trento, and the Swiss Federal Office for Agriculture (BLW) project 04.24.3.3. This study was conducted within the framework of COST Action 864 'PomeFruitHealth'. We thank H. U. Höpli, T. Paternoster, and A. Hussistein for providing apple plants and pear fruit; and M. Stadler for providing technical assistance.

\section{LITERATURE CITED}

Andersen, G. L., Beattie, G. A., and Lindow S. E. 1998. Molecular characterization and sequence of a methionine biosynthetic locus from $\mathrm{Pseu}$ domonas syringae. J. Bacteriol. 180:4497-4507.

Babini, V., and Mazzucchi, U. 2000. Competence of pear shootand fruit wounds for Erwinia amylovora infections. J. Plant Pathol. 82:147-150.

Bassler, B. L., Wright, M., Showalter, R. E., and Silverman, M. R. 1993. Intercellular signalling in Vibrio harveyi: Sequence and function of genes regulating expression of luminescence. Mol. Microbiol. 9:773786.

Bassler, B. L., Wright, M., and Silverman, M. R. 1994. Multiple signalling systems controlling expression of luminescence in Vibrio harveyi: Sequence and function of genes encoding a second sensory pathway. Mol. Microbiol. 13:273-286.

Bassler, B. L., Greenberg, E. P., and Steven, A. M. 1997. Cross-species induction of luminescence in the quorum-sensing bacterium Vibrio harveyi. J. Bacteriol. 179:4043-4045.

Beer, S. V., Bauer, D. W., Jiang, X. H., Laby, R. J., Sneath, B. J., Wei, Z. M., Wilcox, D. A., and Zumoff, C. H. 1991. The hrp gene cluster of Erwinia amylovora. Pages 53-60 in: Advances in Molecular Genetics of Plant-Microbe Interactions, vol. 1. H. Hennecke and D. P. S. Verma, eds. Kluwer Academic Publishers, Dordrecht, The Netherlands.

Blachinsky, D., Shtienberg, D., Zamski, E. Weinthal, D., and Manulis, S. 2006. Effects of pear tree physiology on fire blight progression in perennial branches and on expression of pathogenicity genes in Erwinia amylovora. Eur. J. Plant Pathol. 116:315-324.

Bogdanove, A. J., Bauer, D. W., and Beer, S. V. 1998. Erwinia amylovora secretes DspE, a pathogenicity factor and functional AvrE homolog, through the Hrp (type III secretion) pathway. J. Bacteriol. 180:22442247

Burse, A., Weingart, H., and Ullrich, M. 2004. NorM, a multidrug efflux pump from Erwinia amylovora involved in competition with other epiphytic bacteria. Appl. Environ. Microbiol. 70:693-703.

Coulthurst, S. J., Lilley, K. S., and Salmond, G. P. 2006. Genetic and proteomic analysis of the role of luxS in the enteric phytopathogen, Erwinia carotovora. Mol. Plant Pathol. 7:31-46.

Dixit, M., Murudkar, C. S., and Rao, K. K. 2002. epr is transcribed from a $\sigma^{\mathrm{D}}$ promoter and is involved in swarming of Bacillus subtilis. J. Bacteriol. 184:596-599.

Doherty, N., Holden, M. T., Qazi, S. N., Williams, P., and Winzer, K. 2006. Functional analysis of luxS in Staphylococcus aureus reveals a role in metabolism but not quorum sensing. J. Bacteriol. 188:2885-2897.

Elgoorani, M. A., and Hassanein, F. M. 1991. The effect of Bacillus subtilis on in vitro growth and pathogenicity of Erwinia amylovora. J. Phytopathol. 133:134-138.

Fong, K. P., Gao, L., and Demuth, D. R. 2003. $\operatorname{lux} S$ and $\operatorname{arcB}$ control aerobic growth of Actinobacillus actinomycetemcomitans under iron limitation. Infect. Immun. 71:298-308.

González Barrios, A. F., Zuo, R., Hashimoto, Y., Yang, L., Bentley, W. E., and Wood, T. K. 2006. Autoinducer 2 controls biofilm formation in Escherichia coli through a novel motility quorum-sensing regulator (MqsR, B3022). J. Bacteriol. 188:305-316.

Gordon Bonn, W., and van der Zwet, T. 2000. Distribution and economic importance of fire blight. Pages 37-53 in: Fire Blight, the Disease and its Causative Agent, Erwinia amylovora. J. L. Vanneste, ed. CABI Publishing, Oxon, U.K.

Greenberg, E. P., Hastings, J. W., and Ulitzur, S. 1979. Induction of luciferase synthesis in Beneckea harveyi by other marine bacteria. Arch. Microbiol. 120:87-91.

Herzberg, M., Kaye, I. K., Peti, W., and Wood, T. K. 2006. YdgG (TqsA) controls biofilm formation in Escherichia coli K-12 through autoinducer 2 transport. J. Bacteriol. 188:587-598.

Huynh, T. V., Dahlbeck, D., and Staskawicz, B. J. 1989. Bacterial blight of soybean: Regulation of a pathogen gene determining host cultivar specificity. Science 245:1374-1377.

Johnson, K. B., Stockwell, V. O., McLaughlin, R. J., Sugar, D., Loper, J. E., and Roberts, R. G. 1993. Effect of bacterial antagonists on establishment of honey bee-dispersed Erwinia amylovora in pear blossoms and on fire blight control. Phytopathology 83:995-1002.

Johnson, K. B., and Stockwell, V. O. 1998. Management of fire blight: A case study in microbial ecology. Annu. Rev. Phytopathol. 36:227-248.

Jock, S., Donat, V., Lopez, M. M., Bazzi, C., and Geider, K. 2002. Following spread of fireblight in Western, Central and Southern Europe by molecular differentiation of Erwinia amylovora strains with PFGE analysis. Environ. Microbiol. 4:106-114.

Khan, M. A., Duffy, B., Gessler, C., and Patocchi, A. 2006. QTL mapping of fire blight resistance in apple. Mol. Breed. 17:299-306.

Kumar, S., Tamura, K., Jakobsen, I. B., and Nei, M. 2001. MEGA2: Molecular evolutionary genetics analysis software. Bioinformatics 17:1244-1245.

Laasik, E., Andresen, L., and Mäe, A. 2006. Type II quorum sensing regulates virulence in Erwinia carotovora ssp. carotovora. FEMS (Fed. Eur. Microbiol. Soc.) Microbiol. Lett. 258:227-234.

Lee, S. J., Park, S. Y., Lee, J. J., Yum, D. Y., Koo, B. T., and Lee, J. K. 2002. Genes encoding the $N$-acyl homoserine lactone-degrading enzyme are widespread in many subspecies of Bacillus thuringiensis. Appl. Environ. Microbiol. 68:3919-3924.

Loper, J. E., Henkels, M. D., Roberts, R. G., Grove, G. G., Willett, M. J., 
and Smith, T. J. 1991. Evaluation of streptomycin, oxytetracycline, and copper resistance of Erwinia amylovora isolated from pear orchards in Washington State. Plant Dis. 75:287-290.

McManus, P. S., Stockwell, V. O., Sundin, G. W., and Jones, A. L. 2002. Antibiotic use in plant agriculture. Annu. Rev. Phytopathol. 40:443-465.

Mergaert, J., Hauben, L., Cnockaert, M. C., and Swings, J. 1999. Reclassification of non-pigmented Erwinia herbicola strains from trees as Erwinia billingiae sp. nov. Int. J. Syst. Bacteriol. 49:377-383.

Metzger, M., Bellemann, P., Bugert, P., and Geider, K. 1994. Genetics of galactose metabolism of Erwinia amylovora and its influence on polysaccharide synthesis and virulence of the fire blight pathogen. J. Bacteriol. 176:450-459.

Miller, M. B., Skorupski, K., Lenz, D. H., Taylor, R. K., and Bassler, B. L. 2002. Parallel quorum sensing systems converge to regulate virulence in Vibrio cholerae. Cell 110:303-314.

Miller, S. T., Xavier, K. B., Campagna, S. R., Taga, M. E., Semmelhack, M. F., Bassler, B. L., and Hughson, F. M. 2004. Salmonella typhimurium recognizes a chemically distinct form of the bacterial quorum-sensing signal AI-2. Mol. Cell 15:677-687.

Mok, K. C., Wingreen, N. S., and Bassler, B. L. 2003. Vibrio harveyi quorum sensing: A coincidence detector for two autoinducers controls gene expression. EMBO (Eur. Mol. Biol. Organ.) J. 22:870-881.

Molina, L., Constantinescu, F., Michel, L., Reimmann, C., Duffy, B., and Défago, G. 2003. Degradation of pathogen quorum-sensing molecules by soil bacteria: A preventive and curative biological control mechanism. FEMS (Fed. Eur. Microbiol. Soc.) Microbiol. Ecol. 45:71-81.

Molina, L., Rezzonico, F., Défago, G., and Duffy B. 2005. Autoinduction in Erwinia amylovora: Evidence of an acyl-homoserine lactone signal in the fire blight pathogen. J. Bacteriol. 187:3206-3213.

Momol, M. T., Norelli, J. L., Piccioni, D. E., Momol, E. A., Gustafson, H. L., Cummins, J. N., and Aldwinckle, H. S. 1998. Internal movement of Erwinia amylovora, through symptomless apple scion tissues into the rootstock. Plant Dis. 82:646-650.

Neiditch, M. B., Federle, M. J., Miller, S. T., Bassler, B. L., and Hughson, F. M. 2005. Regulation of LuxPQ receptor activity by the quorum-sensing signal autoinducer-2. Mol. Cell 18:507-518.

Oh, C.-S., and Beer, S. V. 2005. Molecular genetics of Erwinia amylovora involved in the development of fire blight. FEMS (Fed. Eur. Microbiol. Soc.) Microbiol. Lett. 253:185-192.

Pei, D., and Zhu, J. 2004. Mechanism of action of S-ribosylhomocysteinase (LuxS). Curr. Opin. Chem. Biol. 8:492-497.

Prentki, P., and Krisch H. M. 1984. In vitro insertional mutagenesis with a selectable DNA fragment. Gene 29:303-313.

Pusey, P. L. 2000. The role of water in epiphytic colonization and infection of pomaceous flowers by Erwinia amylovora. Phytopathology 90:13521357.

Reading, N. C., and Sperandio, V. 2006. Quorum sensing: The many languages of bacteria. FEMS (Fed. Eur. Microbiol. Soc.) Microbiol. Lett. 254:1-11.

Rezzonico, F., Moënne-Loccoz, Y., and Défago, G. 2003. Effect of stress on the ability phlA-based quantitative competitive PCR assay to monitor biocontrol strain Pseudomonas fluorescens CHA0. Appl. Environ. Microbiol. 69:686-690.

Rozen, S., and Skaletsky, H. J. 2000. Primer3 on the www for general users and for biologist programmers. Pages 365-386 in: Bioinformatics Methods and Protocols: Methods in Molecular Biology. S. Krawetz and S. Misener, eds. Humana Press, Totowa, NJ, U.S.A.

Sambrook, J., Fritsch, E. F., and Maniatis, T. 1989. Molecular Cloning: A Laboratory Manual. Cold Spring Harbor Laboratory Press, Cold Spring Harbor, NY, U.S.A.

Schulte, R., and Bonas, U. 1992. A Xanthomonas pathogenicity locus is induced by sucrose and sulfur-containing amino acids. Plant Cell 4:79-86.

Simon, R., Priefer, U., and Puhler, A. 1983. A broad host range mobilization system for in vitro genetic engineering: Transposition mutagenesis in gram negative bacteria. Biotechnology 1:784-791.

Sperandio, V., Torres, A. G., and Kaper, J. B. 2002. Quorum sensing Escherichia coli regulators B and C (QseBC): A novel two-component regulatory system involved in the regulation of flagella and motility by quorum sensing in E. coli. Mol. Microbiol. 43:809-821.

Sperandio, V., Torres, A. G., Jarvis, B., Cataro, J. P., and Kaper J. B. 2003. Bacteria-host communication: The language of hormones. Proc. Natl. Acad. Sci. U.S.A. 100:8951-8956.

Stockwell, V. O., Johnson, K. B., Sugar, D., and Loper, J. E. 2002. Antibiosis contributes to biological control of fire blight by Pantoea agglomerans strain Eh252 in orchards. Phytopathology 92:1202-1209.

Surette, M. G., and Bassler, B. L. 1998. Quorum sensing in Escherichia coli and Salmonella typhimurium. Proc. Natl. Acad. Sci. U.S.A. 95:7046-7050.

Surette, M. G., and Bassler, B. L. 1999. Regulation of autoinducer production in Salmonella typhimurium. Mol. Microbiol. 31:585-595.

Taga, M. E., Miller, S. T., and Bassler, B. L. 2003. Lsr-mediated transport and processing of AI-2 in Salmonella typhimurium. Mol. Microbiol. 50:1411-1427.

Thompson, J. D., Higgins, D. G., and Gibson, T. J. 1994. CLUSTAL W: Improving the sensitivity of progressive multiple sequence alignment through sequence weighting, position-specific gap penalties and weight matrix choice. Nucleic Acids Res. 22:4673-4680.

Thomson, S. V. 2000. Epidemiology of fire blight. Pages 9-36 in: Fire Blight, the Disease and its Causative Agent, Erwinia amylovora. J. L. Vanneste, ed. CABI Publishing, Oxon, U.K.

Turovskiy, Y., and Chikindas, M. L. 2006. Autoinducer-2 bioassay is a qualitative, not quantitative method influenced by glucose. J. Microbiol. Methods 66:497-503.

van Houdt, R., Moons, P., Jansen, A., Vanoirbeek, K., and Michiels, C. W. 2006. Isolation and functional analysis of luxS in Serratia plymuthica RVH1. FEMS (Fed. Eur. Microbiol. Soc.) Microbiol. Lett. 262:201-209.

Vendeville, A., Winzer, K., Heurlier, K., Tang, C. M., and Hardie, K. R. 2005. Making 'sense' of metabolism: Autoinducer-2, LuxS and pathogenic bacteria. Nat. Rev. Microbiol. 3:383-396.

Venturi, V., Venuti, C., Devescovi, G., Lucchese, C., Friscina, A., Degrassi, G., Aguilar, C., and Mazzucchi, U. 2004. The plant pathogen Erwinia amylovora produces acyl-homoserine lactone signal molecules in vitro and in planta. FEMS (Fed. Eur. Microbiol. Soc.) Microbiol. Lett. 24:179-183.

Voisard, C., Bull, C. T., Keel, C., Laville, J., Maurhofer, M., Schnider, U., Défago, G., and Haas, D. 1994. Biocontrol of root diseases by Pseudomonas fuorescens CHA0: Current concepts and experimental approaches. Pages 67-89 in: Molecular Ecology of Rhizosphere Microorganisms. F. O'Gara, D. N. Dowling, and B. Boesten, eds. Wiley-VCH Verlag, Weinheim, Germany.

Walther, I., Pippia, P., Meloni, M. A., Turrini, F., Mannu, F., and Cogoli, A. 1998. Simulated microgravity inhibits the genetic expression of interleukin-2 and its receptor in mitogen-activated $\mathrm{T}$ lymphocytes. FEBS (Fed. Eur. Biochem. Soc.) Lett. 436:115-118.

Wang, L., Hashimoto, Y., Tsao, C.-Y., Valdes, J. J., and Bentley, W. E. 2005. Cyclic AMP (cAMP) and cAMP receptor protein influence both synthesis and uptake of extracellular autoinducer 2 in Escherichia coli. J. Bacteriol. 187:2066-2076.

Wei, Z. M., Laby, R. J., Zumoff, C. H., Bauer, D. W., He, S. Y., Collmer, A., and Beer, S. V. 1992. Harpin, elicitor of the hypersensitive response produced by the plant pathogen Erwinia amylovora. Science 257:85-88.

Wei, Z., Kim, J. F., and Beer, S. V. 2000. Regulation of hrp genes and type III protein secretion in Erwinia amylovora by HrpX/HrpY, a novel twocomponent system, and HrpS. Mol. Plant-Microbe Interact. 13:12511262 .

Wengelnik, K., and Bonas, U. 1996. HrpXv, an AraC-type regulator, activates expression of five of the six loci in the hrp cluster of Xanthomonas campestris pv. vesicatoria. J. Bacteriol. 178:3462-3469.

Winzer, K., Hardie, K. R., and Williams, P. 2002. Bacterial cell-to-cell communication: Sorry, can't talk now-gone to lunch! Curr. Opin. Microbiol. 5:216-222.

Winzer, K., Hardie, K. R., and Williams, P. 2003. LuxS and autoinducer-2: Their contribution to quorum sensing and metabolism in bacteria. Adv. Appl. Microbiol. 53:291-396.

Xavier, K. B., and Bassler, B. L. 2005. Regulation of uptake and processing of the quorum-sensing autoinducer AI-2 in Escherichia coli. J. Bacteriol. 187:238-248.

Yap, M.-N., Yang, C.-H., Barak, J. D., Jahn, C. E., and Charkowski, A. O. 2005. The Erwinia chrysanthemi type III secretion system is required for multicellular behavior. J. Bacteriol. 187:639-648.

Zhang, Y., Merighi, M., Bazzi, C., and Geider, K. 1998. Genomic analysis by pulsed-field gel electrophoresis of Erwinia amylovora strains from the Mediterranean region including Italy. J. Plant Pathol. 80:225-232.

Zhao, Y., Blumer, S. E., and Sundin, G. W. 2005. Identification of Erwinia amylovora genes induced during infection of immature pear tissue. J. Bacteriol. 187:8088-8103.

\section{AUTHOR-RECOMMENDED INTERNET RESOURCE}

Wellcome Trust Sanger Institute Erwinia amylovora webpage: www.sanger.ac.uk/Projects/E_amylovora 